\title{
Current Progress in Rheoforming of Wrought Aluminum Alloys: A Review
}

\author{
Gan $\mathrm{Li}^{1,2}{ }^{1}$, Hongxing $\mathrm{Lu}^{2, *}$, Xiaogang $\mathrm{Hu}^{1}{ }^{1}$, Feng $\mathrm{Lin}^{2}$, Xinwei $\mathrm{Li}^{1}$ and Qiang $\mathrm{Zhu}{ }^{1, *}$ \\ 1 Department of Mechanical and Energy Engineering, Southern University of Science and Technology, \\ Shenzhen 518055, China; 11963005@mail.sustech.edu.cn (G.L.); huxg@sustech.edu.cn (X.H.); \\ lixw@sustech.edu.cn (X.L.) \\ 2 School of Innovation and Entrepreneurship, Southern University of Science and Technology, \\ Shenzhen 518055, China; 11849292@mail.sustech.edu.cn \\ * Correspondence: luhx@sustech.edu.cn (H.L.); zhuq@sustech.edu.cn (Q.Z.)
}

Received: 31 December 2019; Accepted: 6 February 2020; Published: 11 February 2020

\begin{abstract}
Semi-solid processing (SSP), including rheoforming and thixoforming, offers a promising opportunity to manufacture net-shaped parts with complex structure and excellent mechanical properties. Owing to its low cost and short process, rheoforming has been the subject of extensive study over the last two decades. The interest in the rheoforming of wrought aluminum alloys is progressively growing among both the research and industrial communities. This review starts with reviewing the recent efforts and advances on preparation of semi-solid slurry of wrought $\mathrm{Al}$ alloys, followed by discussing the correlation between microstructure and performance of these alloys. Finally, special attention is paid in the industrial application and the future trends of rheoforming of wrought aluminum alloys.
\end{abstract}

Keywords: rheoforming; wrought aluminum alloys; semi-solid slurry; microstructure; mechanical properties

\section{Introduction}

Wrought aluminum alloys, as a class of pervasive structural materials, are broadly used in aerospace and automobile sectors due to their low density, high strength to weight ratio and natural availability [1-4]. Currently, most parts made of wrought aluminum alloys are fabricated by plastic forming and precision machining $[5,6]$. However, these traditional approaches usually remain a few issues in terms of cost, production efficiency and complex geometry, which restrict their wider applications seriously. Semi-solid processing (SSP), as a promising near net-shape forming method for the metallic materials, is a competitive technique to satisfy the increasing demand of parts with complex structure and excellent mechanical properties [7-9].

Generally, SSP is categorized into two routes: rheoforming, in which the alloy is controlled cooling to the semi-solid state and then injected into a die without an intermediate solidification step, and thixoforming, which involves reheating of solid billets to a semi-solid temperature range and followed by forming operation. Over the past two decades, an obvious trend can be found that rheoforming has been the subject of extensive study due to many merits, such as its lower cost and shorter process [10-13].

The key success and first step of rheoforming is to produce excellent semi-solid slurries with qualitied spheroidal microstructure and certain solid fraction as a feedstock, which play a critical role in properties of the final parts [14]. The unique slurry, which is temperature- and time-dependent, ensure the alloy manifest thixotropic behavior when sheared [15-17]. The practical result of this rheology is laminar, smooth die filling and hence the common defects found in conventional die casting 
can be easily averted, resulting in structural parts with excellent mechanical properties which can also undergo means of heat treatment [18-22]. Furthermore, lower processing temperature always leads to less solidification shrinkage, reducing thermal shock to the die and closer to net shape. On the other hand, in contrast to forging, complex products can be made in one shot with less cost. Therefore, SSP can benefit from both casting and forging.

At present, the most common $\mathrm{Al}$ alloys for rheoforming that have been applied practically are Al-Si cast alloys, especially the A356, A357 and 319s alloys [23-25]. However, the mechanical and some physical properties of these alloys are usually relatively poor, making it hard to fully fulfill the requirements of lightweight and low energy consumption. Hence, there is a strong drive to develop $\mathrm{Al}$ alloys with better properties, such as the 2xxx series, 6xxx series, and 7xxx series wrought aluminum alloys. In recent years, rheoforming of wrought $\mathrm{Al}$ alloys has attracted increasing interest and some progress has been achieved. Nevertheless, from the many technologies available, only a handful is able to produce parts that meet the demands of industrial applications.

Even though a series of review papers has been published on semi-solid processing of $\mathrm{Al}$ alloys [15,23,24,26-36], no comprehensive review about rheoforming of wrought Al alloys has been reported. This paper aims at reviewing the recent development of rheoforming of wrought aluminum alloys. In Section 2, recent efforts and advances on preparation of semi-solid slurry of wrought $\mathrm{Al}$ alloys are reviewed. The correlation of microstructure and properties of these alloys will be discussed in Section 3. In Section 4, special attention is paid in the industrial application, and the future trends and prospects of the rheoforming of wrought Al alloys are put forward in Section 5.

\section{Slurry Preparation of Wrought Al Alloys}

\subsection{Possibility Analysis of Slurry Preparation}

Slurry preparation is one of the most critical steps for rheoforming, and its primary goal is to prepare slurry with uniformly distributed fine globules. Considering that there is a controlled cooling from the liquid state to the liquid-solid region in the slurry preparation process, the solidification behaviors of the alloy wrought 7075 analyzed by Differential Scanning Calorimetry (DSC) under virous kinetic conditions $\left(1,5,10,15,20 \mathrm{~min} /{ }^{\circ} \mathrm{C}\right)$. The cast Al-Si alloy 319s was also analyzed for comparison between the two type of alloys. The measured DSC cooling curves of 7075 and 319s alloys are shown in Figure 1a,b. Three exothermic peaks (labeled peak 1, peak 2 and peak 3) can be evidently found in these curves. According to the thermodynamic simulation under the non-equilibrium Scheil model, the phase transformations are recognized and illustrated. It can be easily found that faster cooling rates lead to higher exothermic peaks. This is because the phase transformations at faster rate leads to less time to occur and always need more output of thermal energy, resulting in larger exothermic peaks. It can also be noted that a slight increase in semi-solid range is observed as the cooling rates increase.

As shown in Figure 1c,d, the liquid fraction versus temperature curves of 7075 and 319s at different cooling rates are calculated using tangent method based on the cooling curves. In addition, the variations in liquid fraction with temperature under Scheil model are also shown for reference. Generally, the "processing window" for rheoforming means that temperature interval for a certain liquid/solid fraction, and the prepared slurry with a solid fraction of $0.3 \sim 0.5$ is suitable. The liquidus, solidus and rheofoming windows for 7075 and 319s alloys at different cooling rates and thermodynamic predictions are given in Table 1. As for 319s, the solidification range of 7075 also increases with increasing cooling rate, while the rheoforming window is relative stable in comparison with the change of the solidification range in both alloys. However, it is clear that there are an extremely narrow rheoforming window and time window for 7075 alloy, indicating that in order to obtain qualitied slurry, the solidification process should be controlled much more accurately than for the cast Al-Si 319s alloy. 

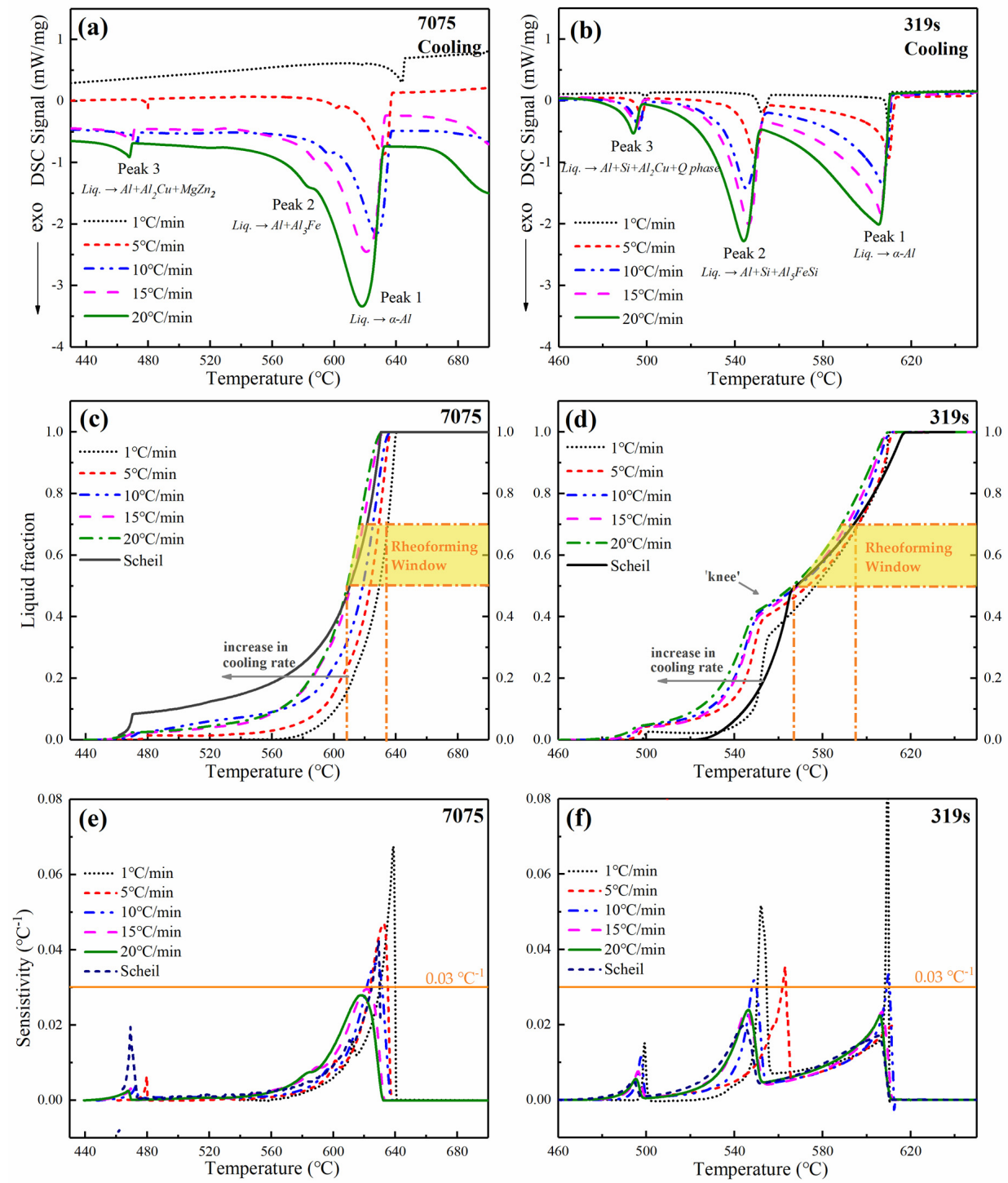

Figure 1. Measured DSC signal of 7075 (a) and 319s (b) alloys at different cooling rates, calculated liquid fraction curves of 7075 (c) and 319s (d) alloys, the temperature sensitivity of 7075 (e) and 319s (f) alloys.

Table 1. Rheoforming windows and solidification ranges for the 7075 and 319s alloys.

\begin{tabular}{|c|c|c|c|c|c|c|}
\hline Alloy & $\begin{array}{l}\text { Cooling } \\
\text { Rate } \\
\left({ }^{\circ} \mathrm{C} / \mathrm{s}\right)\end{array}$ & $\begin{array}{c}\text { Solidus } \\
\left({ }^{\circ} \mathrm{C}\right)\end{array}$ & $\begin{array}{l}\text { Liquidus } \\
\left({ }^{\circ} \mathrm{C}\right)\end{array}$ & $\begin{array}{c}\text { Solidification } \\
\text { Range } \\
\left({ }^{\circ} \mathrm{C}\right)\end{array}$ & $\begin{array}{l}\text { Rheoforming } \\
\text { Window } \\
\left({ }^{\circ} \mathrm{C}\right)\end{array}$ & $\begin{array}{c}\text { Time } \\
\text { Window } \\
\text { (s) }\end{array}$ \\
\hline \multirow[t]{6}{*}{7075} & Scheil & 461.3 & 630.3 & 169 & 10.9 & - \\
\hline & 1 & - & 644.7 & - & 4.6 & 276 \\
\hline & 5 & 478.6 & 634.8 & 156.2 & 5.5 & 66 \\
\hline & 10 & 470.9 & 633.5 & 162.6 & 6.5 & 39 \\
\hline & 15 & 464.5 & 627.4 & 162.9 & 5.5 & 36 \\
\hline & 20 & 463.0 & 626.5 & 163.5 & 7.9 & 23.7 \\
\hline \multirow[t]{6}{*}{$319 \mathrm{~s}$} & Scheil & 508.4 & 611.5 & 103.1 & 26.1 & - \\
\hline & 1 & 498.0 & 609.9 & 111.9 & 19.6 & 1176 \\
\hline & 5 & 494.8 & 612.4 & 117.6 & 22.8 & 273.6 \\
\hline & 10 & 492.1 & 609.6 & 117.5 & 23.6 & 141.6 \\
\hline & 15 & 490.6 & 609.4 & 118.8 & 22.1 & 88.4 \\
\hline & 20 & 489.3 & 608.4 & 119.1 & 22.4 & 67.2 \\
\hline
\end{tabular}


According to the study by Tzimas and Zavalianglos [37], a key parameter to control the SSP has been initially proposed that the variation in liquid fraction with temperature $\mathrm{d} f \mathrm{~L} / \mathrm{d} T$ of the alloy should be as low as possible to ensure the stability and reproducibility of the process. Lower values of $\mathrm{d} f L / \mathrm{d} T$ lead to a smaller change of solid fraction sensitive to temperature change and hence the solid fraction is easier to control. Since the study by Tzimas, many authors have contributed to the development of the temperature sensitive of solid fraction. Liu et al. [38] established the famous and widely used criteria: a maximum temperature sensitive of $0.03{ }^{\circ} \mathrm{C}^{-1}$ to determine whether the process is stable. The temperature sensitive of the 7075 and 319s alloys are presented in Figure 1e,f. For the 319s alloy, all the temperature sensitivities between $0.3-0.5$ solid fraction at different kinetic conditions and thermodynamic simulation are below this criterion, while the $319 \mathrm{~s}$ alloy is a suitable alloy for semisolid processing. In contrast, the same results can be obtained at higher cooling rates $\left(15-20 \mathrm{~min} \cdot{ }^{\circ} \mathrm{C}^{-1}\right)$ for 7075 alloy while almost all the temperature sensitivities between $0.3-0.5$ solid fraction at lower rates (1-10 $\mathrm{min} \cdot{ }^{\circ} \mathrm{C}^{-1}$ ) exceed $0.03{ }^{\circ} \mathrm{C}^{-1}$. Obviously, increasing the cooling rates improve the processability but with a shorter time window simultaneously (see Table 1).

On the other hand, very recently, the enthalpy sensitivity of liquid fraction has been suggested by $\mathrm{Hu}$ et al. [39] as a novel and effective criterion for assessing the semi-solid processability. Likewise, their results also indicated that the wrought alloys with higher enthalpy sensitivity are more difficult to be rheoformed than the cast alloys.

Figure 2 demonstrates the liquid fraction curves of some common wrought and Al-Si cast alloys used in rheoforming. Comparing the solidification routes and liquid fraction curves of wrought and cast alloys, it can be noted that there is a "knee" (eutectic point) at around 0.6 solid fraction for the cast Al-Si alloys, resulting from the presence of silicon (Si), to have a reminder for the slurry preparation. Virtually, adding silicon into the wrought alloys can not only depress the temperature sensitivity significantly and reduce solidification shrinkage, but also improve the flowability, but with an inevitable decrease in mechanical behaviors.

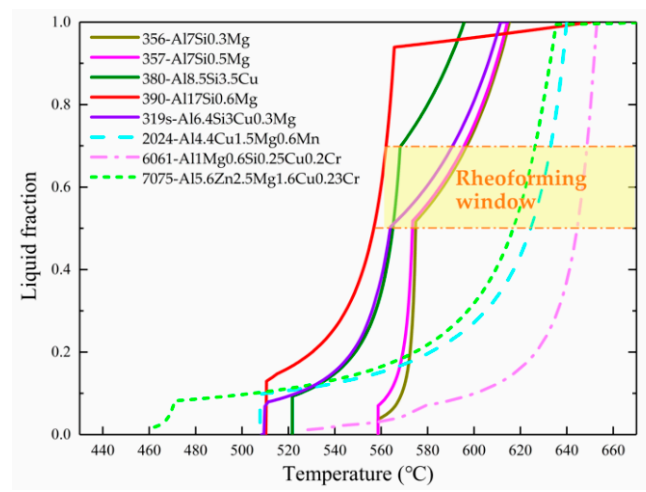

Figure 2. The liquid fraction curves based on the results of numerical simulaiton for some common aluminum alloys employed in rheoforming (Thermo-Calc 2019a software under the Scheil model).

Surprisingly, inspired by the experiments by Curle et al. on rheocasting of Al-Si binary eutectic alloy [40], pure $\mathrm{Al}$ [41], Zhang and co-workers [42] found that rheoforming can occur even there is no theoretical temperature interval between the solidus and liquidus because of the kinetics of solidification. Accordingly, for the wrought alloys, ideal slurry in which the primary particles are fine, spherical, and uniformly dispersed in the matrix can also be prepared if the solidification process is strictly controlled in spite of their higher temperature and enthalpy sensitivity.

\subsection{Methods of Slurry Preparation}

In practice, the slurry was usually prepared in a container. If no measures are taken during the solidification process, and then strictly controlled, there will be a steep temperature gradient (i.e., a larger solid fraction difference) from the edge to the center along the radius because the exterior 
slurry is chilled by the container wall. That can result in more complex flow behavior and increased possibility of turbulence formation, which pose limitations on the performance of the parts. So far, based on diverse solidification conditions, around 30 kinds of methods for reducing the temperature difference during slurry preparation process have been developed. These methods can be divided into two main categories: agitation and non-agitation. In historical terms, it was generally acknowledged that only though the dendrite fragmentation can obtain slurry in the infancy stage of SSP development [43]. To achieve that many methods based on diverse agitation such as mechanical or electromagnetic stirring, were proposed to obtain semi-solid slurry with thixotropic structure. Subsequently, in the early 21st century, some researchers found that semi-solid structure of spherical primary alpha phase can also be prepared without breaking off dendrites. Several powerful methods were introduced, including new rheocasting (NRC) [44], continuous rheoconversion process (CRP) [43] and the semi-solid rheocasting (SSR) [45], etc. Essentially, both categories require numerous nuclei during the initial stage of solidification to obtain better stability of the growing spheroids in a semi-solid bath. If the grain density is not sufficiently high, the resulting structure is traditional coarse dendrites, unbecoming for rheoforming [46].

Among all the methods, only approximately a half of them have been used to prepare the slurry of wrought alloys. As listed in Table 2, the solid fraction ( $f s$ ), the average particles diameter (APD) and the shape factor $\left(\mathrm{S}_{\mathrm{F}}\right)$ of the primary particles and the required time, as well as the mass of the liquid metal for some wrought alloys are presented and compared to those of cast alloys A356/A357 for different methods derived from literature. Almost all the methods can prepare good slurry with APD less than $100 \mu \mathrm{m}$ and $S_{\mathrm{F}}$ more than 0.5 within $1 \mathrm{~min}$. In addition, with the same method, there is no obvious distinction between the wrought and cast alloys at a certain solid fraction in terms of shape factor, the average particles diameter and required time.

From a different perspective, most methods can prepare high-quality slurry while still demonstrating some common issues. Firstly, many methods have not been developed for making high solid fraction, which cannot show its great potential and obtain maximum benefits [47]. In high solid fraction rheoforming, the slurry commonly flows in a laminar manner, resulting in higher product quality with near porosity-free, faster cycle time and extended tool life $[47,48]$. The second problem, as displayed in Table 2, is that few of these methods is able to produce slurry with heavier mass (e.g., $3 \mathrm{~kg}$ ) at one shot, which poses limitation on good combination between production efficiency and product weight. In fact, increasing the mass of the poured metal usually deteriorates the quality of the prepared slurry. Moreover, entrainment defects always formed during the slurry preparation, leading to parts with non-competitive mechanical properties [49]. In essential, slurry preparation is a melt treatment technology before forming and hence the slurry was easily involved in gas and oxide film in various ways [50]. For example, in some methods, such as SEED [51] or CSIP-RCS [52], the melt scours the channel or crucible intensely during pouring, causing entrainment defects. In addition, in some methods like LSPSF [53], SIM [54], and SCP [55], the melt flows through a certain length of pouring channel under the combination action of pouring and gravity while scouring the inner wall of the pouring channel intensely, leading to entrapment defects. These defects can also occur when the melt flowing out of the pouring channel is injected directly into the slurry collection crucible, mold cavity or injection chamber due to strong turbulence resulting from its high flow velocity.

In addition to these methods mentioned in Table 2, there are some other processes focusing on the rheoforming of wrought alloys, such as Cooling Slope (CS) [56], CSIR-RCS [57,58], and Enthalpy Compensation Process (ECP) $[59,60]$, whereas no more details about the prepared slurry can be found in existed literatures. The addition of rare elements such as Sc, Zr is also effective in further refining the $\alpha$-Al grains. For example, Zhao et al., [61] successfully prepared slurry of 7A04 alloy (a Chinese code) with $5 \mathrm{~kg}$ with the addition of Sc and $\mathrm{Zr}$ elements, which can generate large quantities of $\mathrm{Al}_{3}(\mathrm{Zr}, \mathrm{Sc})$ particles to act as good heterogeneous nucleants for $\alpha$-Al grains, thus leading to finer microstructure. Interestingly, air-cooled stirring rod (ACSR) processing [62], a relatively novel method initially invented by Kang et al., that can produce excellent slurry with the solid fraction of $55 \%$ and the grain size of 
$15 \mu \mathrm{m}$ and the shape factor of 0.86 in a short time. Unfortunately, this amazing method has not been used to wrought alloys. 
Table 2. Statistics of fraction solid, particle size, shape factor, preparation time and mass of slurry of some cast and wrought alloys prepared by different method.

\begin{tabular}{|c|c|c|c|c|c|c|c|}
\hline Process & Affiliation (Country) & Alloy & Fs $(\%)$ & $D p(\mu m)$ & $S_{F}$ & Time & Mass \\
\hline \multirow[t]{2}{*}{1 Gas Induced Semi-solid (GISS) } & Massachusetts Institute of Technology (USA) & A356 [63] & $0-14.6$ & $7.3-68.4$ & $0.79-0.73$ & $5-45 s$ & $2 \mathrm{~kg}$ \\
\hline & & $7075[64]$ & $13.3-27.2$ & $29.3-44.7$ & - & $5-20 s$ & $1 \mathrm{~kg}$ \\
\hline \multirow[t]{3}{*}{$\begin{array}{l}2 \text { Swirled Enthalpy Equilibration Device } \\
\text { (SEED) }\end{array}$} & Aluminum Company of Canada (Canada) & A356 [51] & $30-45$ & $70-110$ & - & $30-60 \mathrm{~s}$ & $1-6 \mathrm{~kg}$ \\
\hline & & $7075[65]$ & 45 & 106.65 & 0.61 & - & $1 \mathrm{~kg}$ \\
\hline & & $7108[66]$ & $\sim 55$ & 800 & - & $\sim 220 \mathrm{~s}$ & $2.3 \mathrm{~kg}$ \\
\hline \multirow[t]{2}{*}{3 Indirect Ultrasonic Vibration (IUV) } & Huazhong University of Sci. \& Tech. (China) & A356 [67] & 22.2 & 74 & 0.62 & $50 \mathrm{~s}$ & $\sim 450 \mathrm{~g}$ \\
\hline & & $5083[68]$ & 25 & 60 & 0.54 & $50 \mathrm{~s}$ & $\sim 450 \mathrm{~g}$ \\
\hline \multirow[t]{3}{*}{$\begin{array}{l}4 \text { Low Superheat Pouring with a Shear Field } \\
\text { (LSPSF) }\end{array}$} & Nanchang University (China) & A356 [53] & 41 & 65 & 0.84 & - & - \\
\hline & & 2024 [69] & 55 & 73 & 0.79 & $\sim 25 \mathrm{~s}$ & $1.5 \mathrm{~kg}$ \\
\hline & & $7075[70]$ & $\sim 3$ & 62 & 0.78 & - & - \\
\hline \multirow[t]{3}{*}{5 Self-inoculation method (SIM) } & Lanzhou University of Technology (China) & A356 [54] & 27 & 54.58 & 0.75 & $3 \mathrm{~min}$ & - \\
\hline & & $2024[71]$ & $\sim 25$ & 70.8 & 0.76 & $3 \mathrm{~min}$ & - \\
\hline & & $6061[72]$ & 40 & 76 & 0.8 & $5 \mathrm{~min}$ & - \\
\hline \multirow[t]{2}{*}{6 Forced convection stirring (FCS) } & University of Sci. \& Tech. Beijing (China) & $7075[73]$ & - & 77 & 0.76 & $30 \mathrm{~s}$ & $2 \mathrm{~kg}$ \\
\hline & & $7075[74]$ & - & 64 & 0.88 & $15 \mathrm{~s}$ & $5.3 \mathrm{~kg}$ \\
\hline \multirow[t]{2}{*}{7 Inverted Cone-Shaped Pouring Channel } & University of Sci. \& Tech. Beijing (China) & $7075[75]$ & $\sim 15$ & 60 & 0.86 & $\sim 1 \mathrm{~min}$ & - \\
\hline & & $7075[76]$ & 46 & 78 & 0.85 & - & - \\
\hline \multirow[t]{2}{*}{8 Annular Electromagnetic Stirring (A-EMS) } & General Research Institute for Nonferrous & A357 [77] & - & 44 & - & $10 \mathrm{~s}$ & - \\
\hline & Metals (China) & $7075[78]$ & - & 49 & 0.51 & - & - \\
\hline \multirow[t]{2}{*}{9 Serpentine Channel Pouring (SCP) } & University of Sci. \& Tech. Beijing (China) & A356 [55] & $\sim 15$ & 50 & 0.89 & $10 \mathrm{~s}$ & $3.5 \mathrm{~kg}$ \\
\hline & & 7075 [79] & $\sim 20$ & 64 & 0.78 & $4 \mathrm{~s}$ & $1.6 \mathrm{~kg}$ \\
\hline \multirow[t]{2}{*}{10 Pulsed magnetic field process (PMF) } & Nanchang Hangkong University (China) & A356 [80] & $\sim 20$ & 79 & 0.58 & $4 \mathrm{~min}$ & $600 \mathrm{~g}$ \\
\hline & & 2024 [81] & - & 78 & 0.6 & - & $\sim 1 \mathrm{~kg}$ \\
\hline \multirow[t]{2}{*}{11 Rheo-diecasting process (RDC) } & Brunel University (UK) & A357 [82] & 42 & 41 & 0.87 & $30 \mathrm{~s}$ & - \\
\hline & & 2014 [82] & - & 50 & - & $30 \mathrm{~s}$ & - \\
\hline 12 Rotate Casting Method & Harbin Institute of Technology (China) & 7A09 [83] & - & 52 & 0.67 & - & - \\
\hline 13 A self-developed stirring method & Ferdowsi University of Mashhad (Iran) & $2024[84]$ & 30 & 46 & 0.77 & - & $350 \mathrm{~g}$ \\
\hline
\end{tabular}




\subsection{Flow Behavior and Filling Capacity}

In order to better utilize the rheoforming process, understanding the flow behavior and filling capacity of semi-solid slurry and molten alloy is required. Regarding the molten alloys, Flemings [85] showed that the flow stoppage a thin channel of an alloy is caused by broken dendrite accumulation near the tip when the solid fraction is at the critical solid fraction where the solid particles near the tip develop coherency or interlocking such that there was a sharp decrease in the viscosity and hence the flow is stopped, as illustrated in Figure 3a. Bäckerud et al. [86] suggested that dendrites start impinging and form a network that prevents further flow at a solid fraction of approximately 30 to 35 pct.
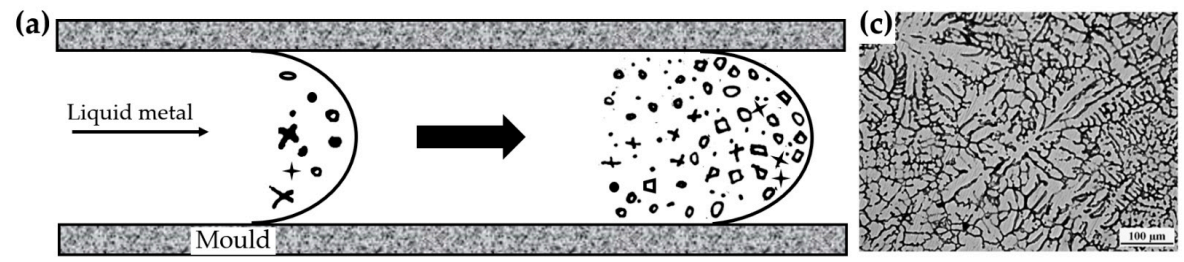

(b)
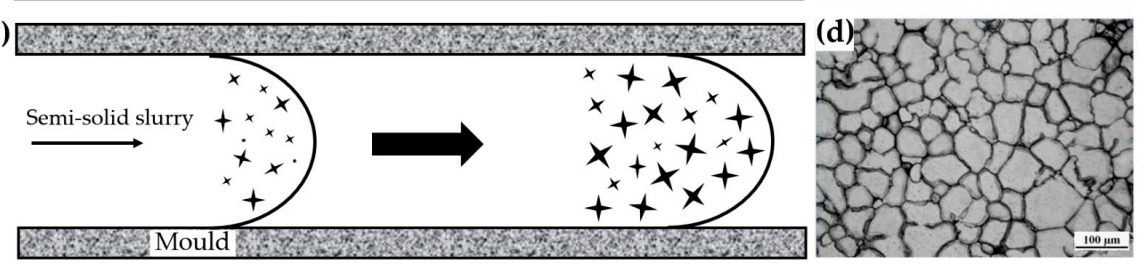

Figure 3. Diagrams of the flow state in a thin channel of (a) liquid metal [85] and (b) semi-solid slurry [64]. Microstructure of $7075 \mathrm{Al}$ alloy fabricated by (c) conventional casting and (d) rheocasting [73], with permission from Elsevier, 2019.

For the semi-solid slurry, on the other hand, microstructure characterizations show uniform dispersed primary solid particles of the slurry before and during the flow in the channel [64]. When the solid particles grow to the size and fraction that yield sufficiently high viscosity, the slurry front stops to flow. Figure $3 \mathrm{~b}$ shows this flow behavior schematically. Rheological behavior experiments and fluidity test results illustrated that the $7075 \mathrm{Al}$ slurries can flow quite well even at medium initial solid fractions $[64,87,88]$. The unique slurry containing fine and solid particles resulting in fine microstructure is in demand as an alternative to the coarse microstructure of conventional manufacturing. A comparison between the microstructure of the 7075 alloy developed by normal casting and rheoforming is shown in Figure $3 c, d$, respectively.

Furthermore, Wu's group [89] asserted that the filling capacity of Al slurry has no significant difference with the molten alloy at the same injection condition, even though much lower than high Silicon containing Al alloys [90]. The fine and homogeneous microstructure of rheofomed $5052 \mathrm{Al}$ parts can be obtained by optimizing the injection pressure and injection speed. Similar results have been reported for 7075 [91] and 7A04 [92] alloys.

\section{Performance of Rheoformed Wrought Al Alloys}

Essential to deal with rheoformed wrought alloys' increasing popularity, the estimation of the feasibility of its use for structural parts through mechanical characterization is ever booming. The microstructural features resulting from unique slurry can potentially yield improved performance. However, the presence of defects from the process, especially for hot cracking, if not sufficiently regulated, may detrimentally affect the performance.

Compared with the Al-Si series alloys, the high strength Al alloys contain low-cost alloying elements (such as $\mathrm{Cu}, \mathrm{Zn}, \mathrm{Mg}, \mathrm{Mn}$ ) strictly chosen to engender complex strengthening phases during subsequent ageing. These elements usually bring about large solidification intervals of more than $130^{\circ} \mathrm{C}$, as shown in Figures $1 \mathrm{c}$ and 2, thereby leading to hot tearing during the final stages of solidification due to material shrinkage, a challenging issue that has been hard to grapple with since 
the first age-hardenable alloy, namely duralumin, was introduced. Owing to the fine global grains and reduced shrinkage offered by the rheoforming, it has been proved that this kind of processing path can immensely minimize and even eliminate crack susceptibility for the wrought $\mathrm{Al}$ alloys. With the rapid advancements in rheoforming over the past two decades, massive experiments have been conducted to investigate the superior performance of rheoformed wrought alloys. This section will present a sequence of performance that have received researchers' attention in the literature.

\subsection{Mechanical Properties}

\subsubsection{Tensile Behavior}

In recent years, rheoforming of wrought $\mathrm{Al}$ alloys was realized by a sound combination of slurry preparation and different forming paths, such as rolling, squeeze casting (SC) and high pressure die casting (HPDC). Guan et al., for instance, reported that the mechanical properties of rheoformed 2017 [93] and 6201 [94] Al alloys are comparable with conventionally wrought alloys.

The fine spheroidal microstructure and reduced defects resulting from rheoforming primarily leads to enhanced tensile strength and elongation in the as-fabricated condition. Qi et al. [73], for example, showed that compared with conventional HPDC, significantly enhanced tensile strength (543 $\mathrm{MPa}$ ) and elongation (4.1\%) of rheo-HPDC 7075 alloy after T6 heat treatment can be obtained because of the refinement of primary particles and reduction in porosity. Porosity is a destructive structural factor to any casting while the fine-grained structure contributes to an increase of yield strength due to the Hall-Petch effect. A relevant work by Li et al. [56], confirmed that rheo-squeeze casting can form defect-free 7075 part and its mechanical properties are close to forging after appropriate heat treatment. Also, Guo et al. [69] presented that the rheoforming leads to an enhanced increase in tensile strength and elongation of 7075 alloy in comparison with conventional casting because of the reduced occurrence of hot tearing, fine-grained structure as well as the increased relative density. Likewise, the noticeably enhanced mechanical properties resulting from the increased density and finer microstructure of rheoformed parts are also identified in 2xxx, 5xxx, and 6xxx series alloys. Nevertheless, the effect of microstructural features in their studies is not reported.

Chen et al. [95] demonstrated the effect of ultrasonic power on the average grain size and mechanical properties of 2024 alloy. With the increase of power, the mechanical properties increase while the grain size decreases gradually, as displayed in Figure 4. This correlation of grain size and properties is also confirmed by studies on Al-Si alloys [96]. In addition, in order to further minimize the defects and reduce the grain size of the rheoformed parts, the vacuum atmosphere [97] and grain refiner [57] can also be introduced.
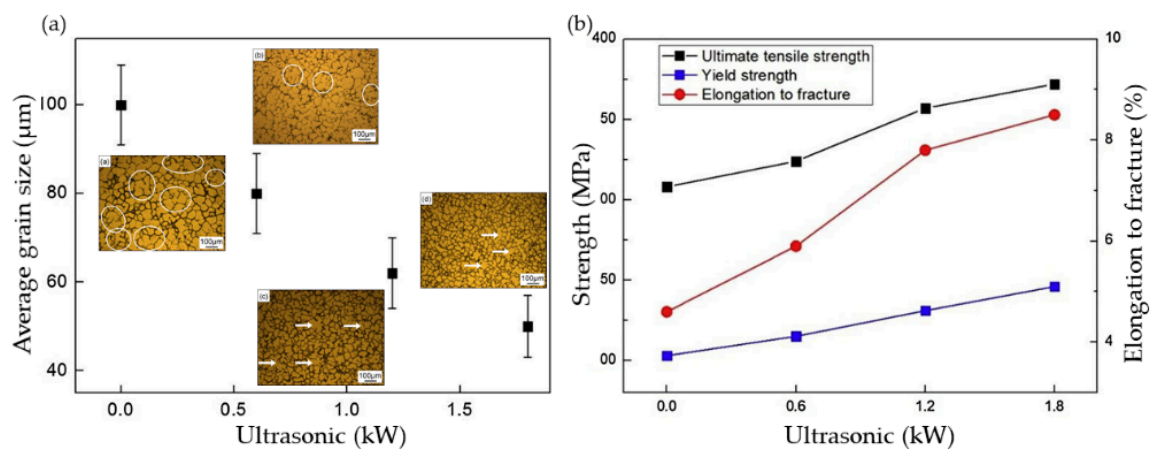

Figure 4. (a) Average grain size and (b) tensile mechanical properties of 2024 aluminum parts prepared by ultrasonic assisted casting [89], with permission from Elsevier, 2019.

In addition to the effect of reduced defects and fine primary $\alpha$-Al grains, the effect of different alloying elements and secondary phases on the properties of rheoformed alloys were also investigated. Möller et al. [98], for instance, exploring the influences of $\mathrm{Cu}$ content and the $(\mathrm{Mg}+\mathrm{Si})$ content as 
well as the Mg:Si ratio on the mechanical properties of rheo-HPDC 6xxx series Al-Mg-Si-(Cu) alloys, noted that the addition of $\mathrm{Cu}$ and excess Si result in higher strength and hardness in both T4 and T6 conditions and a natural pre-ageing has a major effect on the subsequent T6 properties of 6xxx alloys. They concluded that the good combination of strength and ductility can be achieved for the 6063 alloy, which has the highest Mg:Si ratio and hence incipient melting during solution heat treatment is limited.

Regarding the influence of secondary phases, some experiments have been conducted to understand how the precipitation, distribution and shape of secondary phases contribute to the performance of rheoformed alloys. In general, the solidification of the melt in the rheoforming process always experiences two stages. Take rheo-HPDC as an example, the former solidification mainly occurs in slurry preparation, including rapid cooling, stirring or other ways, and then quick transfer to HPDC machine while the latter mainly occurs when the slurry enters the shot chamber and mold cavity during filling, as depicted in Figure 5. For example, Li et al. [70], after analyzing the solidification process of the rheoformed 2024 alloy, pointed that the second solidification can be divided into three stages: (1) the secondary primary $\left(\alpha_{2}-\mathrm{Al}\right)$ phase directly grows from the surface of the primary $\alpha-\mathrm{Al}$ phase particles without renucleation, (2) independent nucleation and growth of $\alpha_{3}-\mathrm{Al}$ from residual liquid, and (3) eutectic reaction at the end.

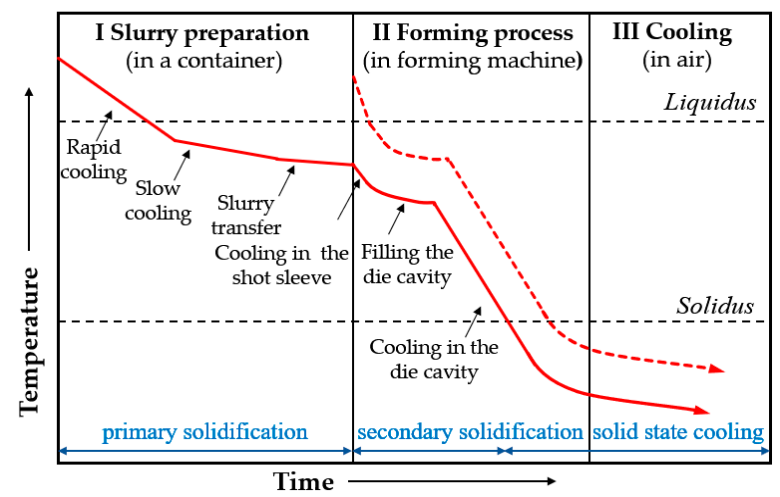

Figure 5. Typical solidification process of the rheo-HPDC (solid line) process and conventional HPDC process (dotted line).

Lü et al. [99] compared the morphology of brittle phase $\mathrm{Mg}_{2} \mathrm{Si}$ of 5052 alloy in the conventional squeeze casting (SC) samples and Rheo-SC samples, noting that some dendritic $\mathrm{Mg}_{2} \mathrm{Si}$ phase with a length of over $50 \mu \mathrm{m}$ was concentrated on grain boundaries in the conventional SC samples, whereas in Rheo-SC sample the $\mathrm{Mg}_{2} \mathrm{Si}$ phase with Chinese-script morphology was uniformly distributed among the primary a-Al particles (Figure 6). The dendritic $\mathrm{Mg}_{2} \mathrm{Si}$ phase can reduce the tensile properties of the alloy, especially the elongation because it acts as stress raiser with poor ductility under a load. Furthermore, they also analyzed SEM images of the tensile fracture for the $5052 \mathrm{Al}$ alloy formed by different process, and concluded that the fine and uniform microstructure of rheo-HPDC and rheo-SC samples led to better tensile behavior than traditional casting. 


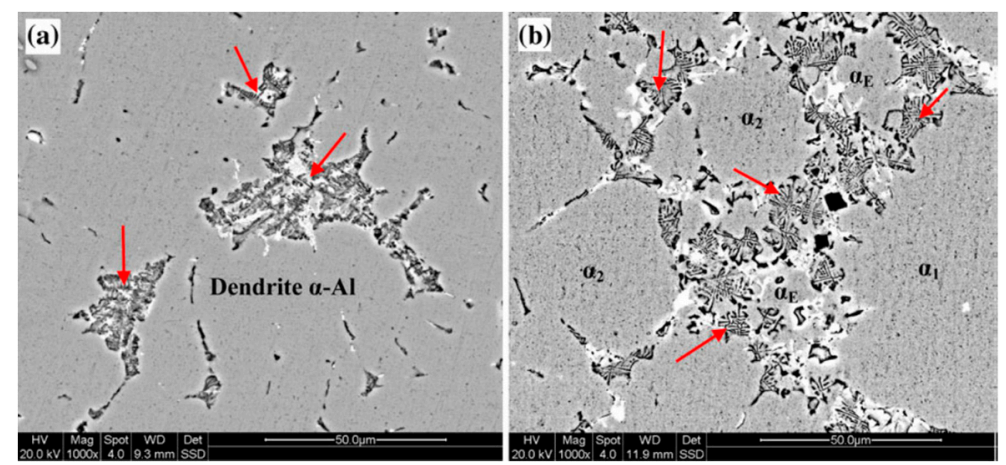

Figure 6. SEM images showing the morphology of $\mathrm{Mg}_{2} \mathrm{Si}$ phase in (a) conventional SC and (b) rheo-SC $5052 \mathrm{Al}$ parts [83].

For the heat-treatable wrought alloys, such as $2 \mathrm{xxx}, 7 \mathrm{xxx}$ series alloys, heat treatment can further enhance their strength, as shown in Figure 7. According to Zhao [100], the solution heat treatment increased the ductility and ultimate tensile strength of non-defects rheo-HPDC 7050 part by $1000 \%$ and $76 \%$, respectively. The conventional $\mathrm{T} 6$ heat treatment, on the other hand, provided the 7050 alloy with a peak strength at the expense of its elongation which dropped by $12 \%$ compared with T4 condition. Similarly, Li et al. [101] compared the effects of different heat treatment conditions on rheoformed 7075 alloy, concluded that T6 heat treatment can yield a compromise between the strength and ductility. Mahathaninwong et al [102], further investigating the effects of T6 condition on the microstructures and tensile behaviors of rheo-HPDC 7075 alloy, noticing that the higher strength can be contributed to the higher number density and finer precipitate size of $\eta^{\prime}$ phase, which was regarded as the main hardening phase while early nucleation of $\eta$ phase in higher aging temperature parts resulted in lower strength.

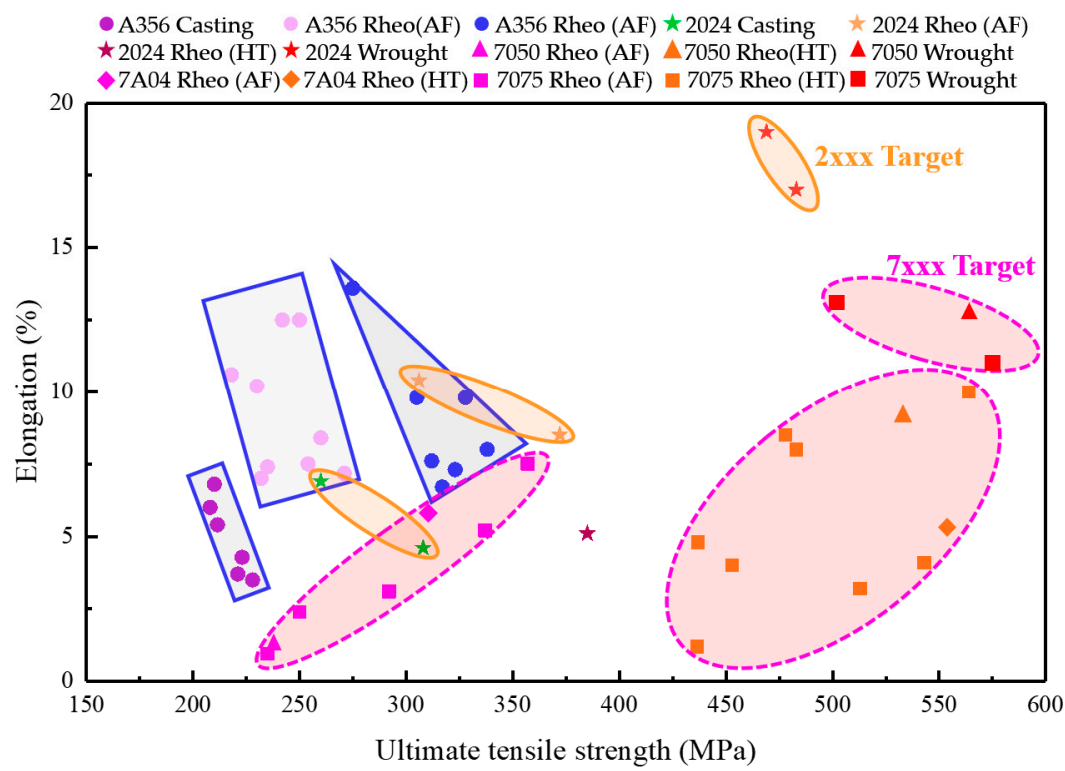

Figure 7. Comparation of tensile behaviors of some wrought $\mathrm{Al}$ alloys and A356 alloy fabricated by conventional casting and rheoforming in the as-fabricated and heat-treated condition $[56,57,69,70,73,78,79,91,95,102-110]$.

Despite having higher strength, the brittleness cannot be overlooked. It should be pointed that even after heat treatment, however, the elongation of rheoformed samples is normally quite lower while the strength can near and even exceed the strength targets of the forging alloys. Serious shrinkage porosity that cannot be eliminated after solution and aging treatment in the rheoformed samples is the 
main cause of the very low resultant elongation, as reported for the Al-Zn-Mg-Cu alloy [91]. Curle [57] also found the porosity in 6082-T6 and 7075-T6 samples caused by incipient melting during solution heat treatment have a negative effect on the elongation, suggesting that optimizing or redesigning the solution heat treatment procedure after determining the melting points of precipitated phase may be beneficial to improve the brittleness. Recent studies on 7050 alloy [100] confirmed their statement and the author proposed that further controlling impurity contents in the alloy would be profitable to the elongation and strength as the eutectic $\mathrm{Si}$ and $\mathrm{Al}_{7} \mathrm{Cu}_{2} \mathrm{Fe}$ phases still exist at grain boundaries as the fracture source after heat treatment.

On the other hand, the comparison of tensile and compressive behavior of rheoformed alloys is still lacking since investigating the compressive behavior of $\mathrm{Al}$ alloys is not generally common due to the material's ductility. Such alloys usually buckle or barrel under compressive tests and the sample size can strongly affect the material's response to compressive loading, complicating the analysis of the detected stress-strain curve.

Overall, it can be concluded that, owing to the unique microstructure of the rheoformed parts and short process, the rheoforming of wrought $\mathrm{Al}$ alloys offers the possibility of fabricating parts benefitting from enhanced strength, ductility, and low cost, concurrently. This combination of properties is an advantage unachievable using the conventional processing techniques.

\subsubsection{Creep Resistance}

An alloy's creep resistance is a very important assessment factor of its time-dependent mechanical properties at elevated temperatures [111]. As for $\mathrm{Al}$ alloys, they are widely known to creep at around 200-300 ${ }^{\circ} \mathrm{C}$. Contrary to the tensile behavior, creep resistance is normally enhanced for larger grain-sized materials. This is because the larger grain size depresses the diffusion rate and limits grain boundaries sliding, which are two phenomena critical for creep. For instance, a prominent enhancement in creep resistance of semi-solid processing A356 alloy in comparison with conventional casting was proved by ESGANDARI et al. [112], who noticed such improvement was contributed to the reduction in the stacking fault energy contributing from the significant dissolution of $\mathrm{Mg}$ in the $\alpha$-Al phase.

Mahathaninwong et al. [113], also reported that although the mechanical response of the rheo-HPDC 7075-T6 Al alloy showed slightly inferior to the wrought counterpart at room temperature while its creep behavior was superior at $200{ }^{\circ} \mathrm{C}$, concluding that slower precipitate coarsening of the rheoformed 7075-T6 Al alloy resulted in lower minimum creep rate and longer creep rupture time (Figure 8). As expected, creep resistance deteriorated as the testing temperature or the stress applied increased [114].

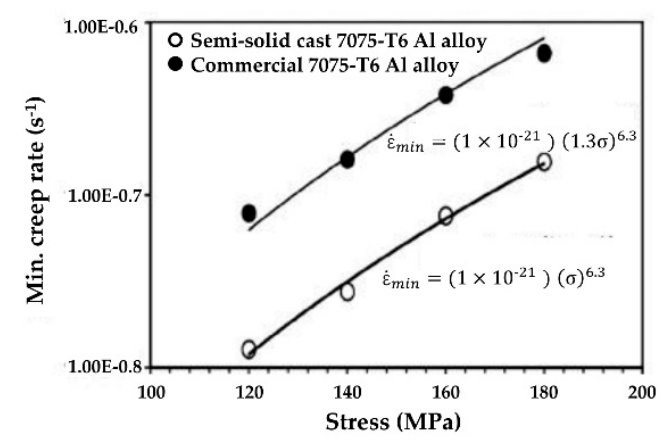

(a)

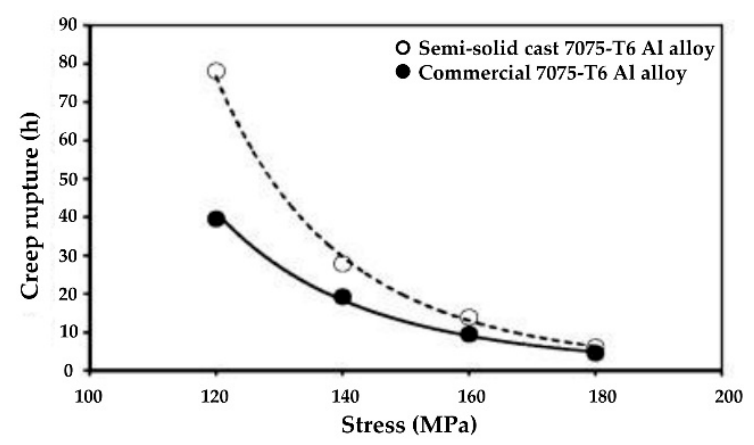

(b)

Figure 8. (a) The stress dependence of minimum creep rate and (b) creep rupture time [107], with permission from Elsevier, 2019.

Even though the creep behavior of rheoformed wrought $\mathrm{Al}$ alloys has not attracted a lot of consideration previously, it is becoming more valuable now since they are progressively being employed in automobile and aerospace industries, where creep resistance is usually of general interest. 


\subsection{Thermal Conductivity}

Investigations on the thermal conductivity of rheoformed $\mathrm{Al}$ alloys are more recent. It is generally acknowledged that the reduced porosity and increased density lead to better thermal conductivity, and hence the thermal conductivity of rheo-HPDC Al alloy is higher than that of HPDC. Similarly, internal work by the authors has demonstrated that the thermal conductivity of rheo-HPDC A357 samples are superior to conventionally HPDC sample. So far, several alloys with high thermal conductivity, including Al-8Si [13,115,116], Al-20Si [117], and Al-25Si [118-120], that are suitable for rheoforming have been developed. However, the thermal conductivity value of these Al-Si alloys is normally less than $180 \mathrm{~W} \cdot \mathrm{m}^{-1} \cdot \mathrm{K}^{-1}$.

Interestingly, A test report on thermal conductivity by Wannasin et al. [121] showed exceptional thermal conductivity of rheoformed 6063 alloy after T6 treatment, in the order of $275 \mathrm{~W} \cdot \mathrm{m}^{-1} \cdot \mathrm{K}^{-1}$, indicating an excellent combination of good mechanical property and superior thermal conductivity. That is because the $\mathrm{Mg}_{2} \mathrm{Si}$ phase can efficaciously increase the diffraction of electrons and hence reducing the average free path of electrons, resulting in satisfactory thermal conductivity. A comparation of thermal conductivity of some popular Al alloys widely used in electronic and communication industries is shown in Figure 9, indicating that rheoforming can observably improve the thermal conductivity, posing an impactful resolvent to remove excessive heat produced during the operation of equipment. Concomitantly, it is worth mentioning that the rheoformed wrought alloy with higher thermal conductivity is also a good conductor for electricity according to the Wiedemann-Franz law. Coupled with its density and price compared to copper $(\mathrm{Cu})$, silver $(\mathrm{Ag})$, and gold $(\mathrm{Au})$, it is attractive for a range of electrical applications.

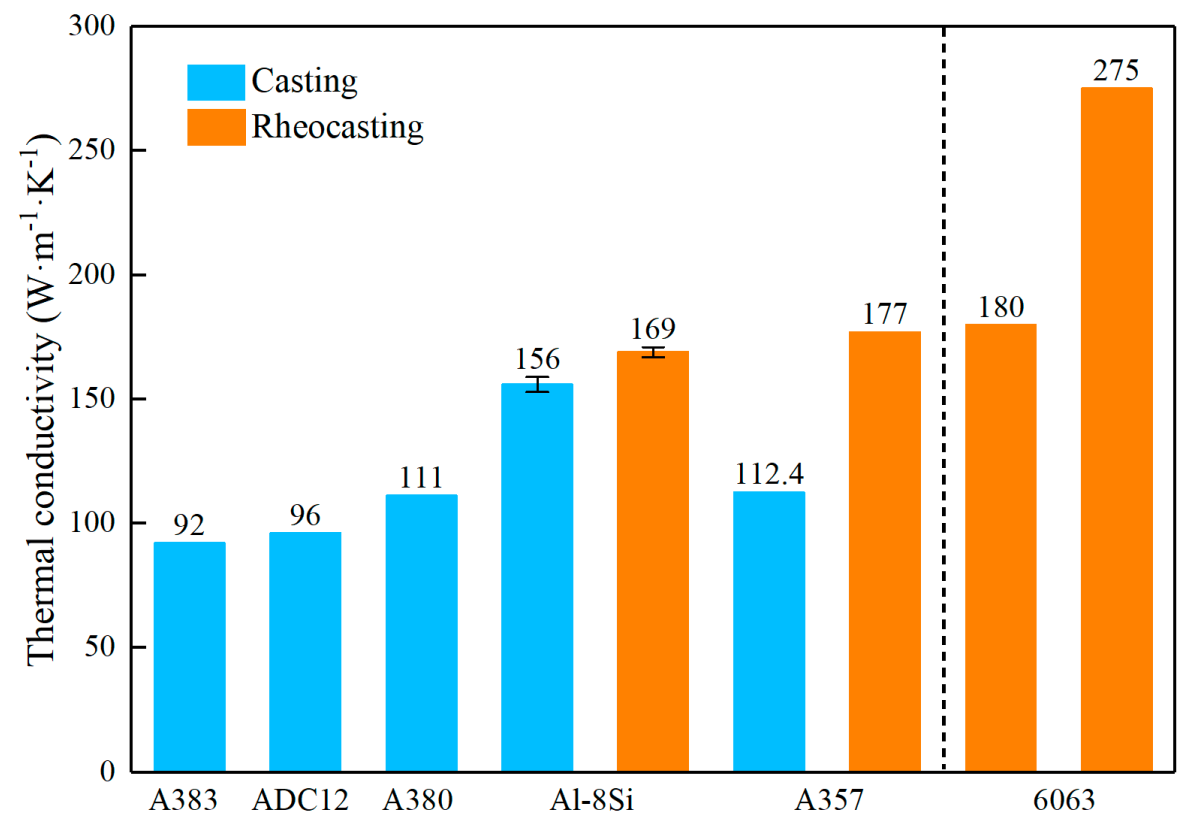

Figure 9. Thermal conductivity of some common Al alloys fabricated by conventional casting and rheoforming [115,116,120-124].

\section{Industrial Application and Opportunities}

In today's manufacturing industry, it is undeniable that the rate of change and innovation is accelerating, leading to robust and sustained development $[125,126]$. In addition to the traditional incremental innovation, the radical innovation has become strategically significant and used as a source of competitive advantage in the global marketplace. In general, the real value of an innovation lies in practical effectuation. The rapid development of rheoforming is a typical example of the full spectrum 
of experiences involved in turning a "research idea" to a successful "commercial product", particularly in the fields of automobile and communication [127-129].

\subsection{Automobile Parts}

In order to grapple with increasingly severe environmental and energy problems, the rheoformed wrought $\mathrm{Al}$ parts have gained more and more popularity in automobile industry due to wrought to weight ratio and low cost. Automobile parts such as shell parts, auto control arm parts, brake calipers or wheel hubs could have improved performance and production efficiency by rheoforming approaches. At present, the rheoforming of Al-Si alloys has been a broadly received industrial manufacturing path to produce high-quality automobile components. Notably, the rheoformed wrought Al alloy parts could provide further enhanced mechanical properties and better fatigue properties in dynamic applications, but low cast for load beating components. Rheoforming can manufacture near net-shape and good surface quality automobile parts thanks to the better mold-filling capacity and reduced shrinkage. As shown in Figure 10a, the outlines of the shell part of the 7075 alloy. As shown in Figure 10a, the outlines of the shell part are clearly discernible without obvious defects even though its edge is thin. Figure 10b,c display the color anodized wrought parts with good appearance, high surface quality and mechanical properties, indicating that these rheoformed wrought $\mathrm{Al}$ parts are satisfactory. The 2024 alloy frame-shaped part prepared by conventional and ultrasonic assisted conventional SC is displayed in Figure 10d and the thickness of the its thinnest part is only $4 \mathrm{~mm}$. The contours of the part are clear without obvious defects, manifesting that the mold filling of the rheoforming process is well-pleasing. It should be attributed to the good flow behavior of the slurry and high forming pressure during SC. Therefore, it can be concluded that wrought Al parts with complex shape and thin wall could be fabricated by the rheoforming process.
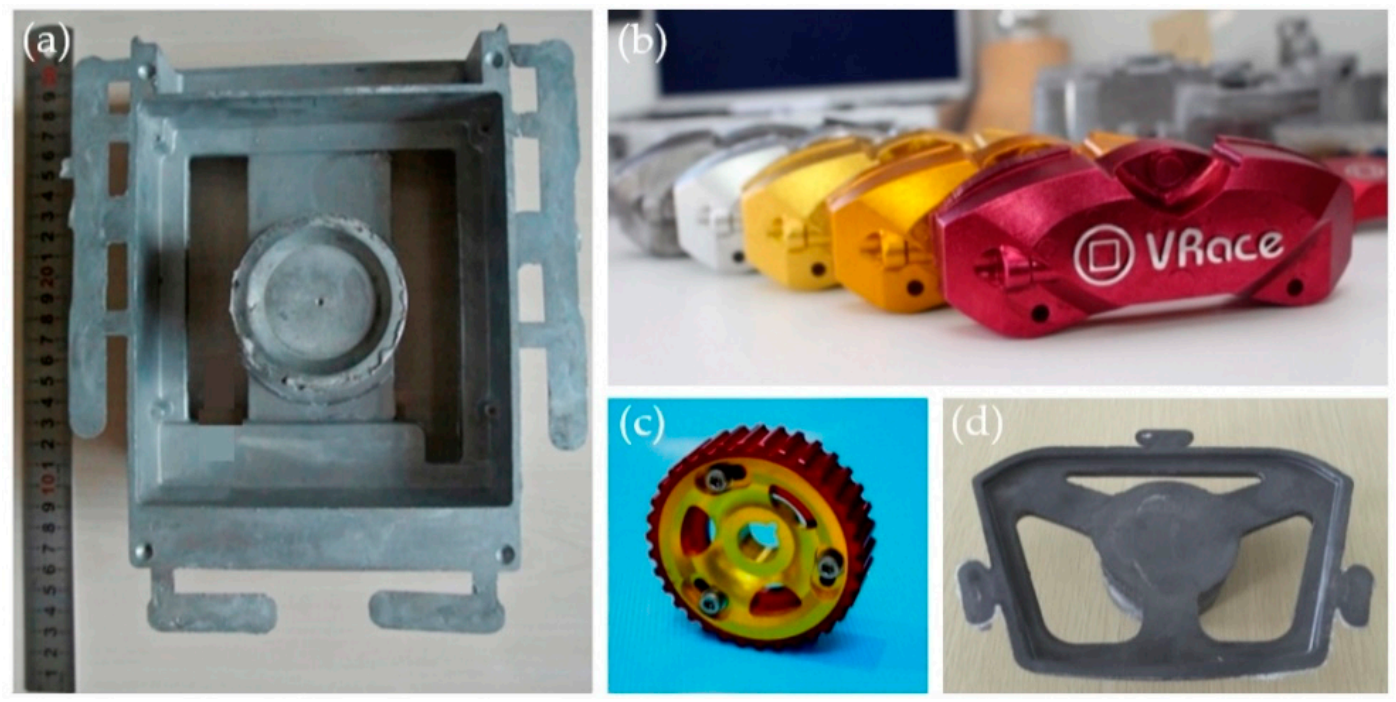

Figure 10. (a) $7075 \mathrm{Al}$ shell part farbricated by the FCR [73], with permission from Elsevier, 2019. (b) Color anodized 7075 brake caliper parts and (c) gear fabricated by GISS [121]. (d) $2024 \mathrm{Al}$ frame-shaped part fabricated by UV [95], with permission from Elsevier, 2019.

\subsection{Communication Parts}

With the advent of the 5G era and the further upgrade of modern communication technology, the demand for communication parts with high thermal conductivity and good mechanical properties gradually grows. These communication components usually have multifarious shapes and sizes which are often highly customized for various applications. Furthermore, they always have complex structure with thin-wall shapes and hence they are often made of $\mathrm{Al}$ alloys because the parts must have both good mechanical properties and high efficiency for conducting heat concurrently. Rheoformed Al-Si 
parts can satisfy these meets in most cases, but the parts with further improved thermal conductivity and electroconductibility provided by wrought alloys are still highly desired. As shown in Figure 11, the telecom component fabricated by 6063Al RheoMetal with thin wall can reach $28.0 \mathrm{~m} \Omega / \mathrm{m}$ and $180 \mathrm{~W} \cdot \mathrm{m}^{-1} \cdot \mathrm{K}^{-1}$ at $20{ }^{\circ} \mathrm{C}$ [116]. It confirmed that the rheoforming of wrought alloys can render the creation of unique microstructure, leading to better thermal and electrical properties than conventional cast alloys. Also, Li et al. [101] showed that rheoforming of high strength Al alloy 7075 is also suitable for fabricating thin-welled communication parts with complex internal structure and higher accuracy compared to traditional casting routes. The thickness of inner wall and external wall can reach $0.5 \mathrm{~mm}$ and $1 \mathrm{~mm}$, respectively, while no defects were detected according to the $X$ ray test.

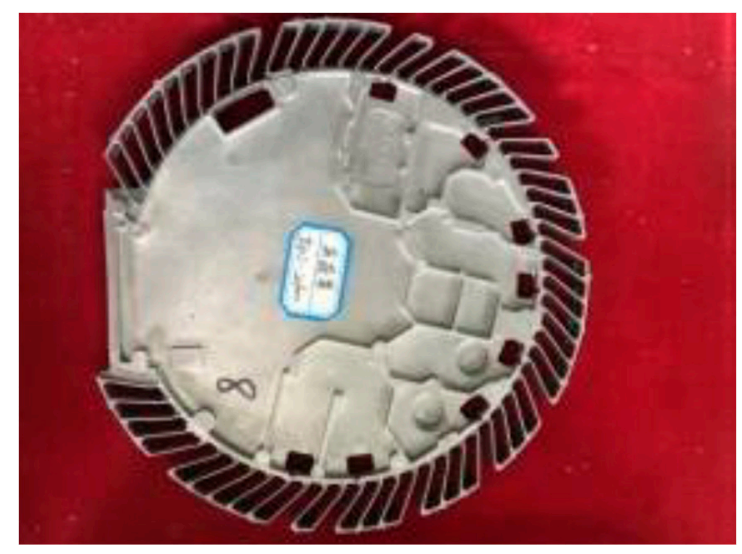

Figure 11. $6063 \mathrm{Al}$ telecom part farbricated by the RheoMetal [130].

On the other hand, anodizing of wrought $\mathrm{Al}$ alloy parts can improve the surface appearance and corrosion resistance, which can be used for decorative purposes, proposing another direction for the rheoformed wrought Al alloys [131,132]. For instance, the new generation smart phones provided by the world's largest cell phone makers, such as Apple iPhone 11, HUAWEI P30 Pro, and SAMSUNG NOTE 10+, choose the wrought Al alloys as their frame due to not only lightweight and high mechanical properties, but also more choices of color.

\section{Summary and Outlook}

Rheoforming of wrought $\mathrm{Al}$ alloys is becoming more common-both on the research and industrial levels - with recent breakthroughs and efforts made in the field. This paper demonstrates a comprehensive review of recent progress on rheoforming of wrought Al alloys. The challenges and current advancements of the semi-solid slurry preparation have been identified and compared. In addition, the performance, advantages and industrial applications of rheoformed wrought Al alloys have been discussed.

From half a century of study on rheoforming, several benefits can be obtained in comparison with competivitive manufacturing routes, such as conventional HPDC, plastic forming, and even selective laser melting. However, rheoforming has not been seen as a common technology and its market is relatively limited. As a consequence, some confinement is required to direct the future study into the aspects that can better improve the standing of the technology. Several future trends and prospects are proposed, based on the existing papers about rheoforming and materials-science, as following:

(1) Alloys need to be designed for their processing route. Specific 'wrought alloys' and 'cast alloys' have been developed while so far research and development (R \& D) on 'rheoforming (or SSP) alloys' are far from enough. Up until now, almost all the Al alloys used in rheoforming were developed for conventional manufacturing processes, especially the wrought alloys. Due to this, effective control during the slurry preparation is still poor, and the complete understanding of structure-property relationship to further enhance the mechanical properties of the final parts, are still to be realised. 
Therefore, besides the advances regarding the readily-available alloys, there is a strong drive to develop new and reliable alloys specifically for rheoforming for the process that take into account the process needs and the target properties concurrently. For example, there are various requirements for automotive industrial spplications, some need high strength, while some need high fatigue resistance, corrosion resistance and/or wear resistance. Different alloys systmes are needed to fulfill more requirements for industrial applications.

The common approaches to develop new alloys mostly relied on CALPHAD and targeted experiments [133-136], which can not develop a large number of suitable alloys rapidly. The Material Genomic technology such as materials' design softwares and high-throughput methods to experimentally validate the candidate alloys are needed to exploit this capability effectively. This should aim at understanding the effect of the alloying constituents on the processability of the material by rheoforming and ultimately the properties of the fabricated parts in application. Additionally, over the past few years, artificial neural networks (ANN), as a powerful technology that has won numerous contests in pattern recognition and machine learning [137], has also achieved great success in designing new wrought alloys [138], as well as optimizing process parameters in SSP [139].

(2) As disscussed in Section 2.2, the current slurry prepration methods cannot prepare slurry with heavier mass and high solid fraction at a short time. Thus, it is of great importance to develop new methods that can improve the production efficiency and stability of slurry and subsequent forming. Furthermore, owing to the relative movement of liquid and solid phases under pressure forming, there is a certain degree of non-uniformity in the different positions of the larger parts, potentially causing the difference in the performance of the final parts. Accordingly, the performance of rheoformed parts currently is, on the whole, difficult to reach the same level of the forged parts, which is also one of the reasons why rheoforming is difficult to be widely used.

(3) The studies on the performance of rheoformed wrought Al alloy mainly focused on the tensile behavior, but less on the corrosion resistence, fatigue performance, wear resistence as well as mechanical properties at elevated temperature, which are very signifacant and proprobly a precious guide to the broader application of rheoforming in industries. For example, the tribological behavior of a part is of significant importance for applications in the automotive industry where a part can experience a significant amount of friction in the actual use. Hence, such properties need to be ulteriorly explored in future studies.

(4) The market, espcially the automotive industry is very exacting on price and lead time. With a continuous deep development of the artificial intelligence application technology, the highly integrated design and intelligent control of the rheoforming system is the shape of things to come. Special dies and moulds for rheoforming have been designed to enhance the mechanical properties while reducing the cost [140-143]. Moreover, even though the rheoforming of wrought Al alloy can offer considerable cost saving, high performance, and complex struture of parts, it is a quite long process to redesign a new part for rheofoming to replace the original product while meeting the acutual needs of industry, as displayed in Figure 12. Consequently, close cooperation between alloy and process developers and part users, and perseverance at the infancy stage of commercialization are highly needed to bring the rheoforming of wrought $\mathrm{Al}$ alloys to a commercially acceptable level. 


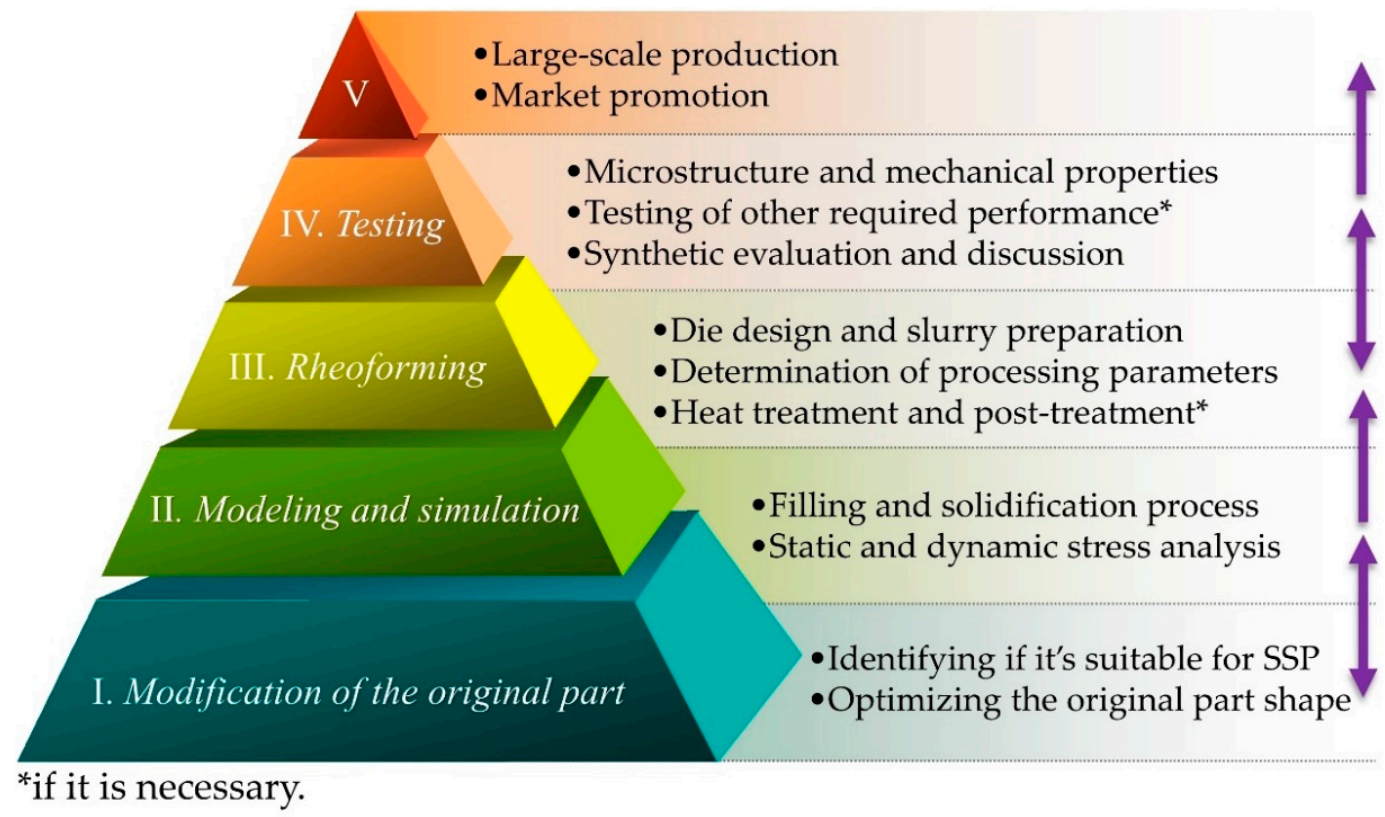

Figure 12. Flow chart of designing a new part for rheofoming to replace the original product.

Author Contributions: G.L. and F.L. prepared the manuscript under the supervision of Q.Z. and H.L.; X.H. and X.L. revised the manuscript. All authors contributed to the general discussion. All authors have read and agreed to the published version of the manuscript.

Funding: This work is financially supported by Shenzhen Science and Technology Innovation Commission (Projects JCYJ20170817110144233, KQTD20170328154443162), National Natural Science and Foundation of China (Grant No. 51805238).

Acknowledgments: The authors would like to thank Cheng Le for his great assistance in DSC experiments.

Conflicts of Interest: The authors declare no conflict of interest.

\section{References}

1. Sun, W.; Zhu, Y.; Marceau, R.; Wang, L.; Zhang, Q.; Gao, X.; Hutchinson, C. Precipitation strengthening of aluminum alloys by room-temperature cyclic plasticity. Science 2019, 363, 972-975. [CrossRef]

2. Williams, J.C.; Starke, E.A. Progress in structural materials for aerospace systems. Acta Mater. 2003, 51, 5775-5799. [CrossRef]

3. Miller, W.S.; Zhuang, L.; Bottema, J.; Wittebrood, A.J.; De Smet, P.; Haszler, A.; Vieregge, A. Recent development in aluminium alloys for the automotive industry. Mater. Sci. Eng. A 2000, 280, 37-49. [CrossRef]

4. Martin, J.H.; Yahata, B.D.; Hundley, J.M.; Mayer, J.A.; Schaedler, T.A.; Pollock, T.M. 3D printing of high-strength aluminium alloys. Nature 2017, 549, 365-369. [CrossRef] [PubMed]

5. Sercombe, T.B.; Schaffer, G.B. Rapid Manufacturing of Aluminum Components. Science 2003, 301, $1225-1227$. [CrossRef] [PubMed]

6. Zhang, H.; Zhu, H.; Qi, T.; Hu, Z.; Zeng, X. Selective laser melting of high strength Al-Cu-Mg alloys: Processing, microstructure and mechanical properties. Mater. Sci. Eng. A 2016, 656, 47-54. [CrossRef]

7. Spencer, D.; Mehrabian, R.; Flemings, M.C. Rheological behavior of $\mathrm{Sn}-15$ pct $\mathrm{Pb}$ in the crystallization range. Metall. Trans. 1972, 3, 1925-1932. [CrossRef]

8. Flemings, M.C. Behavior of metal alloys in the semisolid state. Metall. Trans. B 1991, 22, 269-293. [CrossRef]

9. Zhu, Q.; Midson, S.P. Semi-solid moulding: Competition to cast and machine from forging in making automotive complex components. Trans. Nonferrous Metals Soc. China 2010, 20, 1042-1047. [CrossRef]

10. Wannasin, J.; Canyook, R.; Burapa, R.; Sikong, L.; Flemings, M.C. Evaluation of solid fraction in a rheocast aluminum die casting alloy by a rapid quenching method. Scr. Mater. 2008, 59, 1091-1094. [CrossRef] 
11. Wu, S.; Xie, L.; Zhao, J.; Nakae, H. Formation of non-dendritic microstructure of semi-solid aluminum alloy under vibration. Scr. Mater. 2008, 58, 556-559. [CrossRef]

12. Janudom, S.; Wannasin, J.; Basem, J.; Wisutmethangoon, S. Characterization of flow behavior of semi-solid slurries containing low solid fractions in high-pressure die casting. Acta Mater. 2013, 61, 6267-6275. [CrossRef]

13. Qi, M.F.; Kang, Y.L.; Qiu, Q.Q. Industrialized Application of Rheo-HPDC Process for the Production of Large Thin-Walled Aluminum Alloy Parts. Solid State Phenom. 2019, 285, 453-458. [CrossRef]

14. Flemings, M.; Riek, R.; Young, K. Rheocasting. Mater. Sci. Eng. 1976, 25, 103-117. [CrossRef]

15. Atkinson, H.V. Modelling the semisolid processing of metallic alloys. Prog. Mater. Sci. 2005, 50, $341-412$. [CrossRef]

16. Modigell, M.; Pola, A.; Tocci, M. Rheological Characterization of Semi-Solid Metals: A Review. Metals 2018, 8, 245. [CrossRef]

17. Hu, X.G.; Zhu, Q.; Atkinson, H.V.; Lu, H.X.; Zhang, F.; Dong, H.B.; Kang, Y.L. A time-dependent power law viscosity model and its application in modelling semi-solid die casting of 319s alloy. Acta Mater. 2017, 124, 410-420. [CrossRef]

18. Hu, X.G.; Zhu, Q.; Midson, S.P.; Atkinson, H.V.; Dong, H.B.; Zhang, F.; Kang, Y.L. Blistering in semi-solid die casting of aluminium alloys and its avoidance. Acta Mater. 2017, 124, 446-455. [CrossRef]

19. Lu, H.; Zhu, Q.; Li, D.; He, Y.; Zhang, F. Semi-solid High Pressure Die Casting of High Quality and Complex Shape Aluminum Components. In Proceedings of the International Conference HIGH TECH DIE CASTING 2016, Venice, Italy, 22-23 June 2016.

20. Lu, H.; He, Y.; Midson, S.; Li, D.; Zhu, Q. Controlling and minimizing blistering during T6 heat treating of semi-solid castings. Solid State Phenom. 2016, 256, 192-198. [CrossRef]

21. Lu, H.X.; Zhu, Q.; He, Y.; Zhang, F.; Li, D.Q. Study of forming mechanism of non-filling holes in blades of semi-solid cast impellers. Solid State Phenom. 2016, 256, 314-318. [CrossRef]

22. Zhu, Q.; Midson, S.P.; Ming, C.W.; Atkinson, H.V. Casting and heat treatment of turbocharger impellers thixocast from alloy 201. Solid State Phenom. 2012, 192-193, 556-561. [CrossRef]

23. Atkinson, H.V. Alloys for semi-solid processing. Solid State Phenom. 2013, 192, 16-27. [CrossRef]

24. Rogal, Ł. Critical assessment: Opportunities in developing semi-solid processing: Aluminium, magnesium, and high-temperature alloys. Mater. Sci. Technol. 2017, 33, 759-764. [CrossRef]

25. Liu, D.; Atkinson, H.V.; Kapranos, P.; Jirattiticharoean, W.; Jones, H. Microstructural evolution and tensile mechanical properties of thixoformed high performance aluminium alloys. Mater. Sci. Eng. A 2003, 361, 213-224. [CrossRef]

26. Fan, Z. Semisolid metal processing. Int. Mater. Rev. 2002, 47, 49-85. [CrossRef]

27. Brochu, M.; Verreman, Y.; Ajersch, F.; Bucher, L. Fatigue behavior of semi-solid cast aluminum: A critical review. Solid State Phenom. 2008, 141, 725-730. [CrossRef]

28. Czerwinski, F. Thermomechanical Processing of Metal Feedstock for Semisolid Forming: A Review. Metall. Mater. Trans. B 2018, 49, 3220-3257. [CrossRef]

29. Pola, A.; Tocci, M.; Kapranos, P. Microstructure and properties of semi-solid aluminum alloys: A Literature review. Metals 2018, 8, 181. [CrossRef]

30. Pola, A. Correlation between microstructure and properties of semi-solid products. Solid State Phenom. 2019, 285, 12-23. [CrossRef]

31. Kapranos, P. Current state of semi-solid net-shape die casting. Metals 2019, 9, 1301. [CrossRef]

32. Atkinson, H. Current status of semi-solid processing of metallic materials. In Advances in Material Forming; Springer: Berlin/Heidelberg, Germany, 2007; pp. 81-98.

33. Mohammed, M.N.; Omar, M.Z.; Salleh, M.S.; Alhawari, K.S.; Kapranos, P. Semisolid metal processing techniques for nondendritic feedstock production. Sci. World J. 2013, 2013, 752175. [CrossRef] [PubMed]

34. Nafisi, S.; Ghomashchi, R. Semi-Solid Processing of Aluminum Alloys; Springer-Vaelag: New York, NY, USA, 2016.

35. Deepak, S.; Diran, A.; Rathindra, D. SSM Processing of Hypereutectic Al-Si Alloys-An Overview. In Proceedings of the 8th International Conference on Semi-Solid Processing of Alloys and Composites, Limassol, Cyprus, 21-23 September 2004; pp. 855-864.

36. Nafisi, S.; Ghomashchi, R. Semi-solid metal processing routes: An overview. Can. Metall. Q. 2005, 44, 289-304. [CrossRef] 
37. Tzimas, E.; Zavaliangos, A. Evaluation of volume fraction of solid in alloys formed by semisolid processing. J. Mater. Sci. 2000, 35, 5319-5330. [CrossRef]

38. Liu, D.; Atkinson, H.V.; Jones, H. Thermodynamic prediction of thixoformability in alloys based on the Al-Si-Cu and Al-Si-Cu-Mg systems. Acta Mater. 2005, 53, 3807-3819. [CrossRef]

39. Hu, X.G.; Hu, Z.H.; Qu, W.Y.; Li, X.W.; Li, Z.; Zhou, Y.; Midson, S.P.; Zhu, Q. A novel criterion for assessing the processability of semi-solid alloys: The enthalpy sensitivity of liquid fraction. Materialia 2019, 8, 100422. [CrossRef]

40. Curle, U.A.; Möller, H.; Wilkins, J.D. Shape rheocasting of unmodified Al-Si binary eutectic. Mater. Lett. 2011, 65, 1469-1472. [CrossRef]

41. Curle, U.; Möller, H.; Wilkins, J. Shape rheocasting of high purity aluminium. Scr. Mater. 2011, 64, 479-482. [CrossRef]

42. Zhang, D.; Dong, H.; Atkinson, H. What is the process window for semi-solid processing? Metall. Mater. Trans. A 2016, 47, 1-5. [CrossRef]

43. Pan, Q.; Findon, M.; Apelian, D. The Continuous Rheoconversion Process (CRP): A Novel SSM Approach. In Proceedings of the 8th International Conference on Semi-Solid Processing of Alloys and Composites, Limassol, Cyprus, 21-23 September 2004; p. 56.

44. Mitsuru, A.; Hiroto, S.; Yasunori, H.; Tatsuo, S.; Satoru, S.; Atsushi, Y. Method and Apparatus for Shaping Semisolid Metals. EP Patent 745694, 29 May 1996.

45. Yurko, J.A.; Martinez, R.A.; Flemings, M.C. The Use of Semi-Solid Rheocasting (SSR) for Aluminum Automotive Castings. In Proceedings of the SAE 2003 World Congress \& Exhibition, Detroit, Michigan, 3-6 March 2003.

46. Flemings, M.; Martinez, R.A. Principles of microstructural formation in semi-solid metal processing. Solid State Phenom. 2006, 116, 1-8. [CrossRef]

47. Jorstad, J. SSM Provides Important Advantages; So, why has SSM Failed to Achieve Greater Market Share? Solid State Phenom. 2015, 217, 481-486. [CrossRef]

48. Li, D.Q.; Zhang, F.; Midson, S.P.; Liang, X.K.; Yao, H. Recent developments of rheo-diecast components for transportation markets. Solid State Phenom. 2019, 258, 417-422. [CrossRef]

49. Lu, H. Research on Forming Mechanism and Controlling of Defects of Al-Si Alloy Semi-Solid Die Casting Products. Ph.D. Thesis, General Research Institute for Nonferrous Metals, Beijing, China, June 2017.

50. Guo, H.M.; Zhang, L.W.; Yang, X.J. Two unique issues in rheoforming processes. Chin. J. Nonferrous Metals 2016, 26, 516-525.

51. Lashkari, O.; Nafisi, S.; Ghomashchi, R.; Charette, A.; Langlais, J.; Kulunk, B. Impact of Swirling and Superheat on Microstructural Evolution of 356 Alloy in SEED Slurry on-Demand Process. In Proceedings of the 43rd International Conference of Metallurgists, Hamilton, ON, Canada, 22-25 August 2004; p. 33.

52. Curle, U.A.; Govender, G. Semi-solid rheocasting of grain refined aluminum alloy 7075. Trans. Nonferrous Metals Soc. China 2010, 20, s832-s836. [CrossRef]

53. Guo, H.M.; Yang, X.J.; Wang, J.X. Pressurized solidification of semi-solid aluminum die casting alloy A356. J. Alloys Compd. 2009, 485, 812-816. [CrossRef]

54. Li, M.; Li, Y.D.; Yang, W.L.; Zhang, Y.; Wang, Z.G. Effects of forming processes on microstructures and mechanical properties of A356 aluminum alloy prepared by self-inoculation method. Mater. Res. 2019, 22. [CrossRef]

55. Qi, M.F.; Kang, Y.L.; Zhu, G.M.; Li, Y.D.; Li, W.R. A new Rheo-HPDC process with air-cooled stirring rod device for wireless base station shells of Al-8Si alloy. Solid State Phenom. 2016, 256, 303-308. [CrossRef]

56. Nan, L.; Shuming, X.; Peiwei, B.; Shuqing, Y. Notice of Retraction: A Research on Mechanical Property and Structure of 7075 Wrought Aluminum Alloy Through Pressure Rheocasting. In Proceedings of the 2010 2nd International Conference on Computer Engineering and Technology, Chengdu, China, 16-18 April 2010; pp. 442-446.

57. Curle, U.A. Semi-solid near-net shape rheocasting of heat treatable wrought aluminum alloys. Trans. Nonferrous Metals Soc. China 2010, 20, 1719-1724. [CrossRef]

58. Curle, U.A. Rheocasting an engine mounting bracket in commercial 7075. Mater. Sci. Forum 2011, 690, 133-136. [CrossRef]

59. Li, G.; Lu, H.X.; Hu, X.G.; Zhu, Q. Numerical simulation of slurry making process of 7075 aluminum alloy under electromagnetic field in Rheocasting process. Solid State Phenom. 2019, 285, 373-379. [CrossRef] 
60. Li, G. Development of Semi-Solid Slurry Making Process and Equipment of 7075 Aluminum Alloy. Master's Thesis, Harbin Institute and Technology, Harbin, Heilongjiang Province, China, 30 June 2019.

61. Zhao, J.W.; Guo, A.; Li, H.; Zhang, X.; Han, J.; Wu, S.S. Semisolid slurry of 7A04 aluminum alloy prepared by electromagnetic stirring and Sc, Zr additions. China Foundry 2017, 14, 188-193. [CrossRef]

62. Canyook, R.; Wannasin, J.; Wisuthmethangkul, S.; Flemings, M.C. Characterization of the microstructure evolution of a semi-solid metal slurry during the early stages. Acta Mater. 2012, 60, 3501-3510. [CrossRef]

63. Chucheep, T.; Wannasin, J.; Canyook, R.; Rattanochaikul, T.; Janudom, S.; Wisutmethangoon, S.; Flemings, M.C. Characterization of flow behavior of semi-solid slurries with low solid fractions. Metall. Mater. Trans. A 2013, 44, 4754-4763. [CrossRef]

64. Zhao, Q. Study on the Rheoformability of Semi-Solid 7075 Wrought Aluminum Alloy Using SEED Process. Master's Thesis, University of Quebec at Chicoutimi, Saguenay, QC, Canada, April 2016.

65. Luo, M.; Li, D.; Qu, W.; Liang, X.; Fan, J. Effects of Cooling Rate and Grain Refiner on Semi-solid Rheocasting Slurries of Al-Zn-Mg Alloy. In Proceedings of the Advances in Materials Processing, Singapore, 6-12 July 2018; pp. 829-837.

66. Wu, S.; Lü, S.; Ping, A.; Nakae, H. Microstructure and property of rheocasting aluminum-alloy made with indirect ultrasonic vibration process. Mater. Lett. 2012, 73, 150-153. [CrossRef]

67. Lü, S.; Wu, S.; Lin, C.; Hu, Z.; An, P. Preparation and rheocasting of semisolid slurry of $5083 \mathrm{Al}$ alloy with indirect ultrasonic vibration process. Mater. Sci. Eng. A 2011, 528, 8635-8640. [CrossRef]

68. Guo, H.M.; Yang, X.J. Preparation of semi-solid slurry containing fine and globular particles for wrought aluminum alloy 2024. Trans. Nonferrous Metals Soc. China 2007, 17, 799-804. [CrossRef]

69. Guo, H.M.; Yang, X.J.; Wang, J.X.; Hu, B.; Zhu, G.L. Effects of rheoforming on microstructures and mechanical properties of 7075 wrought aluminum alloy. Trans. Nonferrous Metals Soc. China 2010, 20, 355-360. [CrossRef]

70. Li, Y.L.; Li, Y.D.; Li, C.; Wu, H.H. Microstructure characteristics and solidification behavior of wrought aluminum alloy 2024 rheo-diecast with self-inoculation method. China Foundry 2012, 9, 328-336.

71. Li, M.; Li, Y.D.; Zheng, H.Q.; Huang, X.F.; Chen, T.J.; Ma, Y. Solidification behavior of 6061 wrought aluminum alloy during rheo-diecasting process with self-inoculation method. Trans. Nonferrous Metals Soc. China 2018, 28, 879-889. [CrossRef]

72. Zhou, B.; Kang, Y.-L.; Zhu, G.-M.; Gao, J.-Z.; Qi, M.-F.; Zhang, H.-H. Forced convection rheoforming process for preparation of 7075 aluminum alloy semisolid slurry and its numerical simulation. Trans. Nonferrous Met. Soc. China 2014, 24, 1109-1116. [CrossRef]

73. Qi, M.; Kang, Y.; Zhou, B.; Liao, W.; Zhu, G.; Li, Y.; Li, W. A forced convection stirring process for Rheo-HPDC aluminum and magnesium alloys. J. Mater. Process. Technol. 2016, 234, 353-367. [CrossRef]

74. Yang, B. Preparation of Semi-Solid 7075 Aluminum Alloy Slurry by Inverted Cone-Shaped Pouring Channel Process and Rheo-Diecasting. Ph.D. Thesis, University of Science and Technology, Beijing, China, June 2014.

75. Yang, B.; Mao, W.M.; Song, X.J. Microstructure evolution of semi-solid $7075 \mathrm{Al}$ alloy slurry during temperature homogenization treatment. Trans. Nonferrous Met. Soc. China 2013, 23, 3592-3597. [CrossRef]

76. Zhu, G.; Xu, J.; Zhang, Z.; Bai, Y.; Shi, L. Annular electromagnetic stirring-A new method for the production of semi-solid A357 aluminum alloy slurry. Acta Metall. Sin. 2009, 22, 408-414. [CrossRef]

77. Gao, Z.H.; Xu, J.; Zhang, Z.F.; Tang, M.O. Effect of annular electromagnetic stirring on microstructure and mechanical property of 7075 aluminium alloy. Mater. Sci. Forum 2013, 749, 75-81. [CrossRef]

78. Chen, Z.Z.; Mao, W.M.; Wu, Z.C. Influence of serpentine channel pouring process parameters on semi-solid A356 aluminum alloy slurry. Trans. Nonferrous Metals Soc. China 2011, 21, 985-990. [CrossRef]

79. Zhu, W.Z.; Mao, W.M.; Tu, Q. Preparation of semi-solid 7075 aluminum alloy slurry by serpentine pouring channel. Trans. Nonferrous Met. Soc. China 2014, 24, 954-960. [CrossRef]

80. Zhang, L.; Li, W.; Yao, J.P.; Qiu, H. Effects of pulsed magnetic field on microstructures and morphology of the primary phase in semisolid A356 Al slurry. Mater. Lett. 2012, 66, 190-192. [CrossRef]

81. Zhang, L.; Li, W.; Yao, J.P. Microstructures and thermal stability of the semi-solid 2024 aluminum alloy prepared using the pulsed magnetic field process: Effects of technological parameters. J. Alloys Compd. 2013, 554, 156-161. [CrossRef]

82. Fan, Z.; Fang, X.; Ji, S. Microstructure and mechanical properties of rheo-diecast (RDC) aluminium alloys. Mater. Sci. Eng. A 2005, 412, 298-306. [CrossRef]

83. Wang, Z. Research on Rheological Shearing Preparation Technology of 7A09 Aluminum Alloy Semi-Solid Slurry. Master's Thesis, Harbin Institute and Technology, Harbin, Heilongiiang Province, China, June 2014. 
84. Rahimi, B.; Khosravi, H.; Haddad-Sabzevar, M. Microstructural characteristics and mechanical properties of Al-2024 alloy processed via a rheocasting route. Int. J. Miner. Metall. Mater. 2015, 22, 59-67. [CrossRef]

85. Flemings, M.C. Solidification processing. Metall. Trans. 1974, 5, 2121-2134. [CrossRef]

86. Arnberg, L.; Bäckerud, L.; Chai, G. Solidification Characteristics of Aluminum Alloys: Dendrite Coherency; American Foundrymen's Society: Schaumburg, IL, USA, 1996.

87. Bolouri, A.; Zhao, Q.; Côté, P.; Chen, X.G. Microstructure and rheological properties of semi-solid 7075 slurries using SEED rheocasting process. Solid State Phenom. 2016, 256, 288-293. [CrossRef]

88. Li, Y.; Mao, W.; Zhu, W.; Yang, B. Rheological behavior of semi-solid 7075 aluminum alloy at steady state. China Foundry 2014, 11, 79-84.

89. Lü, S. Study on Prepration and Rheocasting Semisolid Al Alloy Slurry with Ultrasonic Vibration. Ph.D. Thesis, Huazhong University of Science and Technology, Wuhan, China, March 2012.

90. Zhong, G.; Wu, S.; Wan, L.; Qin, B. Study on filling capacity of semi-solid Al-20\%Si alloy prepared by Rheo-casting. China Foundry 2010, 59, 1044-1048.

91. Mao, W.M.; Zhu, W.Z. Tensile properties and microstructure of rheo-diecast 7075 alloy prepared by serpentine channel process. Chin. Foundry 2019, 16, 161-167. [CrossRef]

92. Xu, C.; Zhao, J.; Guo, A.; Li, H.; Dai, G.; Zhang, X. Effects of injection velocity on microstructure, porosity and mechanical properties of a rheo-diecast Al-Zn-Mg-Cu aluminum alloy. J. Mater. Process. Technol. 2017, 249, 167-171. [CrossRef]

93. Guan, R.G.; Wang, S.C.; Wen, J.L.; Liu, X.H. Continuous semisolid extending extrusion process for producing AA2017 aluminium alloy flat bar. Mater. Sci. Technol. 2006, 22, 706-712. [CrossRef]

94. Guan, R.G.; Zhao, Z.Y.; Chao, R.Z.; Lian, C.; Wen, J.L. Simulation of temperature field and metal flow during continuous semisolid extending extrusion process of 6201 alloy tube. Trans. Nonferrous Met. Soc. Chin. 2012, 22, 1182-1189. [CrossRef]

95. Chen, G.; Yang, M.; Jin, Y.; Zhang, H.; Han, F.; Chen, Q.; Zhao, Z. Ultrasonic assisted squeeze casting of a wrought aluminum alloy. J. Mater. Process. Technol. 2019, 266, 19-25. [CrossRef]

96. Haga, T.; Kapranos, P. Simple rheocasting processes. J. Mater. Process. Technol. 2002, 130-131, 594-598. [CrossRef]

97. Kim, H.H.; Kang, C.G. Study of the microstructure and mechanical properties of Al6061 aluminum alloys rheo-forged by vacuum pump. Mater. Sci. Eng. A 2008, 497, 309-321. [CrossRef]

98. Möller, H.; Daswa, P.; Govender, G. The mechanical properties of Rheo-high pressure die cast Al-Mg-Si-(Cu) 6xxx series alloys. Solid State Phenom. 2015, 217-218, 61-66. [CrossRef]

99. Lü, S.; Wu, S.; Wan, L.; An, P. Microstructure and tensile properties of wrought Al alloy 5052 produced by Rheo-Squeeze casting. Metall. Mater. Trans. A 2013, 44, 2735-2745. [CrossRef]

100. Zhao, H. Study on Defects Control, Microstructure and Mechanical Properties of 7050 Aluminum Alloy in Semi-Solid die Casting. Master's Thesis, General Research Institute for Nonferrous Metals, Beijing, China, 5 June 2019.

101. Li, C.; Zhang, Z.F.; Fan, J. Applicaiton research on semi-solid precision forming technology of high strength aluminum alloy. Electro-Mech. Eng. 2016, 32, 49-51. [CrossRef]

102. Mahathaninwong, N.; Plookphol, T.; Wannasin, J.; Wisutmethangoon, S. T6 heat treatment of rheocasting $7075 \mathrm{Al}$ alloy. Mater. Sci. Eng. A 2012, 532, 91-99. [CrossRef]

103. Guan, R.G.; Zhao, Z.Y.; Li, Y.D.; Chen, T.J.; Xu, S.X.; Qi, P.X. Microstructure and properties of squeeze cast A356 alloy processed with a vibrating slope. J. Mater. Process. Technol. 2016, 229, 514-519. [CrossRef]

104. Chen, Z.Z.; Mao, W.M.; Wu, Z.C. Mechanical properties and microstructures of Al alloy tensile samples produced by serpentine channel pouring rheo-diecasting process. Trans. Nonferrous Met. Soc. Chin. 2011, 21, 1473-1479. [CrossRef]

105. MÖLler, H.; Govender, G.; Stumpf, W.E. Application of shortened heat treatment cycles on A356 automotive brake calipers with respective globular and dendritic microstructures. Trans. Nonferrous Met. Soc. Chin. 2010, 20, 1780-1785. [CrossRef]

106. Thanabumrungkul, S.; Janudom, S.; Burapa, R.; Dulyapraphant, P.; Wannasin, J. Industrial development of gas induced semi-solid process. Trans. Nonferrous Met. Soc. Chin. 2010, 20, s1016-s1021. [CrossRef]

107. Moller, H.; Curle, U.A.; Masuku, E.P. Characterization of surface liquid segregation in SSM-HPDC aluminium alloys 7075, 2024, 6082 and A201. Trans. Nonferrous Met. Soc. Chin. 2010, 20, s847-s851. [CrossRef] 
108. Yang, B.; Mao, W.M.; Song, X.J. Microstructure characteristics and mechanical properties of rheocasting 7075 aluminum alloy. Chin. Foundry 2013, 10, 277-281.

109. ASM International Handbook Committee. Properties and Selection: Nonferrous Alloys and Special-Purpose Materials; ASM International: Cleveland, OH, USA, 1990.

110. Jiang, J.; Wang, Y. Microstructure and mechanical properties of the semisolid slurries and rheoformed component of nano-sized $\mathrm{SiC} / 7075$ aluminum matrix composite prepared by ultrasonic-assisted semisolid stirring. Mater. Sci. Eng. A 2015, 639, 350-358. [CrossRef]

111. Aboulkhair, N.T.; Simonelli, M.; Parry, L.; Ashcroft, I.; Tuck, C.; Hague, R. 3D printing of Aluminium alloys: Additive Manufacturing of Aluminium alloys using selective laser melting. Prog. Mater. Sci. 2019, 106, 100578. [CrossRef]

112. Esgandari, B.A.; Nami, B.; Shahmiri, M.; Abedi, A. Effect of Mg and semi solid processing on microstructure and impression creep properties of A356 alloy. Trans. Nonferrous Met. Soc. Chin. 2013, 23, 2518-2523. [CrossRef]

113. Mahathaninwong, N.; Zhou, Y.; Babcock, S.E.; Plookphol, T.; Wannasin, J.; Wisutmethangoon, S. Creep rupture behavior of semi-solid cast 7075-T6 Al alloy. Mater. Sci. Eng. A 2012, 556, 107-113. [CrossRef]

114. Thongkam, S.; Wisutmethangoon, S.; Wannasin, J.; Chantaramanee, S.; Plookphol, T. Creep of Rheocast 7075 aluminum alloy at $300{ }^{\circ} \mathrm{C}$. Appl. Mech. Mater. 2013, 372, 288-291. [CrossRef]

115. Qi, M.; Kang, Y.; Qiu, Q.; Tang, W.; Li, J.; Li, B. Microstructures, mechanical properties, and corrosion behavior of novel high-thermal-conductivity hypoeutectic Al-Si alloys prepared by rheological high pressure die-casting and high pressure die-casting. J. Alloys Compd. 2018, 749, 487-502. [CrossRef]

116. Jarfors, A.E.W.; Zheng, J.C.; Chen, L.; Yang, J. Recent advances in commercial application of the rheometal process in china and europe. Solid State Phenom. 2019, 285, 405-410. [CrossRef]

117. Liu, J.; Wu, S.; Zheng, J. Microstructure and Properties of Semi-solid Die Casting of High Silicon Aluminum Alloy with High Thermal Conductivity. In Proceedings of the Seventh Asia International Symposium on Mechatronics, Xi'an China, 19-22 September 2019; pp. 463-470.

118. Haga, T.; Fuse, H. Semisolid Casting of Product with Thin Fins by Using Al-25\% Si. Key Eng. Mater. 2015, 651-653, 1551-1556. [CrossRef]

119. Haga, T.; Fuse, H. Die-casting of product with thin fins by Al-25\% Si. Adv. Mater. Process. Technol. 2018, 4, 234-243. [CrossRef]

120. Haga, T.; Fuse, H.; Terao, M. Fabrication of thin heat sinks by the die casting of semisolid Al-25\% Si. Solid State Phenom. 2019, 285, 423-428. [CrossRef]

121. Wannasin, J. SSM Slurry Making Process by GISS Technology. In Proceedings of the 2nd International GISS Technology Forum, Shanghai, China, 15-16 July 2019.

122. Shin, J.S.; Ko, S.H.; Kim, K.T. Development and characterization of low-silicon cast aluminum alloys for thermal dissipation. J. Alloys Compd. 2015, 644, 673-686. [CrossRef]

123. Lumley, R.N.; Polmear, I.J.; Groot, H.; Ferrier, J. Thermal characteristics of heat-treated aluminum high-pressure die-castings. Scr. Mater. 2008, 58, 1006-1009. [CrossRef]

124. Tzeng, Y.C.; Chengn, V.S.; Nieh, J.K.; Bor, H.Y.; Lee, S.L. Microstructure and thermal stability of A357 Alloy with and without the addition of Zr. J. Mater. Eng. Perform. 2017, 26, 5511-5518. [CrossRef]

125. Yang, Z.; Shao, S.; Li, C.; Yang, L. Alleviating the misallocation of R\&D inputs in China's manufacturing sector: From the perspectives of factor-biased technological innovation and substitution elasticity. Technol. Forecast. Soc. 2020, 151, 119878.

126. Wojan, T.R.; Crown, D.; Rupasingha, A. Varieties of innovation and business survival: Does pursuit of incremental or far-ranging innovation make manufacturing establishments more resilient? Res. Policy 2018, 47, 1801-1810. [CrossRef]

127. Kirkwood, D.H.; Suéry, M.; Kapranos, P.; Atkinson, H.V.; Young, K.P. Semi-Solid Processing of Alloys; Springer-Vaelag: New York, NY, USA, 2010.

128. Jorstad, J.L. Semi-Solid Metal Processing from an Industrial Perspective; The Best is yet to Come! Solid State Phenom. 2016, 256, 9-14. [CrossRef]

129. Winklhofer, J. Semi-solid casting of aluminium from an industrial point of view. Solid State Phenom. 2019, 285, 24-30. [CrossRef] 
130. Jarfors, A.E.W. Recent Advances in Commercial Application of the Rheometal Process in China and Europe. In Proceedings of the 15th International Conference on Semi-Solid Processing of Alloys and Composites, Shenzhen, China, 22-24 October 2018.

131. Chauke, L.; Möller, H.; Curle, U.A.; Govender, G. Anodising of Al-Mg-Si-(Cu) alloys produced by R-HPDC. Mater. Sci. Forum 2013, 765, 658-662. [CrossRef]

132. Iewkitthayakorn, I.; Janudom, S.; Mahathaninwong, N.; Karrila, S.; Wannasin, J. Anodizing parameters for superheated slurry cast 7075 aluminum alloys. Trans. Nonferrous Met. Soc. Chin. 2019, 29, 1200-1210. [CrossRef]

133. Patel, J.B.; Liu, Y.Q.; Shao, G.; Fan, Z. Rheo-processing of an alloy specifically designed for semi-solid metal processing based on the Al-Mg-Si system. Mater. Sci. Eng. A 2008, 476, 341-349. [CrossRef]

134. Govender, G.; Möller, H.; Curle, U.A. Alloy design for semi solid metal forming. Mater. Sci. Forum 2014, 783-786, 136-141. [CrossRef]

135. Liu, Y.; Fan, Z. Application of thermodynamic calculation to the aluminium alloy design for semi-solid metal processing. Mater. Sci. Forum 2002, 396-402, 717-722. [CrossRef]

136. Proni, C.T.W.; Brollo, G.L.; Zoqui, E.J. A Comparison of the use of ultrasonic melt treatment and mechanical vibration in the manufacture of Al5Si5Zn alloy feedstock for thixoforming. Metall. Mater. Trans. B 2019, 51, 306-317. [CrossRef]

137. Saikia, P.; Baruah, R.D.; Singh, S.K.; Chaudhuri, P.K. Artificial Neural Networks in the domain of reservoir characterization: A review from shallow to deep models. Comput. Geosci. 2020, 135, 104357. [CrossRef]

138. Belayadi, A.; Bourahla, B. Neural network model for 7000 (Al-Z) alloys: Classification and prediction of mechanical properties. Phys. B 2019, 554, 114-120. [CrossRef]

139. Li, H.J.; Qi, L.H.; Han, H.M.; Guo, L.J. Neural network modeling and optimization of semi-solid extrusion for aluminum matrix composites. J. Mater. Process. Technol. 2004, 151, 126-132. [CrossRef]

140. Seo, P.K.; Park, K.J.; Kang, C.G. Semi-solid die casting process with three steps die system. J. Mater. Process. Technol. 2004, 153-154, 442-449. [CrossRef]

141. Kang, C.G.; Seo, P.K.; Kang, S.S. The effect of injection velocity on liquid segregation and mechanical properties in arm part fabricated by semi-solid die casting process. J. Mater. Process. Technol. 2006, 176, 32-40. [CrossRef]

142. Chen, S.; Li, D.Q.; Zhang, F.; He, Y.F.; Zhu, Q.; Li, Y.; Cui, H.X. Development of semi-solid die casting process technology for aluminium alloy clamp. Mater. Sci. Forum 2016, 850, 642-648. [CrossRef]

143. Chen, S.; Zhang, F.; He, Y.F.; Li, D.Q.; Zhu, Q. Development of semi-solid die casting product design and die design technology for aluminium alloy clamp. Solid State Phenom. 2016, 256, 334-339. [CrossRef]

(C) 2020 by the authors. Licensee MDPI, Basel, Switzerland. This article is an open access article distributed under the terms and conditions of the Creative Commons Attribution (CC BY) license (http://creativecommons.org/licenses/by/4.0/). 